4-23-2016

\title{
Conceptions of Authority and the Anglo-American Common Law
} Divide

Dan Priel

Osgoode Hall Law School of York University, dpriel@osgoode.yorku.ca

Source Publication:

American Journal of Comparative Law

Follow this and additional works at: https://digitalcommons.osgoode.yorku.ca/scholarly_works

Part of the Common Law Commons, and the Comparative and Foreign Law Commons

(c) (i) $(9)$

This work is licensed under a Creative Commons Attribution-Noncommercial-No Derivative Works 4.0 License.

\section{Repository Citation}

Priel, Dan, "Conceptions of Authority and the Anglo-American Common Law Divide" (2016). Articles \& Book Chapters. 2412.

https://digitalcommons.osgoode.yorku.ca/scholarly_works/2412

This Article is brought to you for free and open access by the Faculty Scholarship at Osgoode Digital Commons. It has been accepted for inclusion in Articles \& Book Chapters by an authorized administrator of Osgoode Digital Commons. 


\title{
CONCEPTIONS OF AUTHORITY
}

\section{AND THE ANGLO-AMERICAN COMMON LAW DIVIDE} Dan Priel $^{*}$

Forthcoming American Journal of Comparative Law (2016/1 7)

\begin{abstract}
This essay seeks to explain the puzzle of the divergence of American law from the rest of the common law world through the lens of legal theory. I argue that there are four competing ideal-type theories of the authority of the common law: reason, practice, custom, and will. The reason view explains the authority of the common law in terms of correspondence to the demands of pure practical reason; the practice view sees the authority of the common law as derived from the expertise of practitioners (especially judges and practice-oriented academics) who try to develop the common law as a slowly-changing, historically-binding tradition; the custom view sees the authority of the common law as derived from its correspondence to contemporaneous norms and values; and the will view sees the authority of the common law (like that of all other law) as derived from the acts of a sovereign. These competing views imply different answers to various questions (such as the relationship between statutes and the common law, or the role of judges in the legal system). They also lead to very different attitudes towards the idea of a single, supranational common law: generally speaking, the first two approaches are more sympathetic to common law convergence than the latter two. I argue that these days English common law is close to the second, practice-based, conception of common law authority, whereas American law adopts a combination of the third and fourth conceptions. This explains why American common law is largely uninterested in maintaining commonality with other common law jurisdictions, as well as many other differences between American and English common law.
\end{abstract}

\section{The End of the Affair}

In the annals of odd ideas there surely is an entry for a suggestion made by Albert Venn Dicey in a forgotten essay he published in I897. In that essay he suggested "a common citizenship for all Englishmen and Americans." ${ }^{1}$ To a contemporary reader part of why this is surprising has to do with the identity of its author. Dicey is

\footnotetext{
*Associate Professor, Osgoode Hall Law School (dpriel@osgoode.yorku.ca). An early version of this essay was presented in the Obligations VII conference at the University of Hong Kong held in July 20I4, and I thank participants there for their comments and questions. I would also like to thank participants in the Comparative Law Works in Progress Workshop held at Princeton University, and especially to my commentators James Whitman and Peter Dachin, for their comments and suggestions for the paper. Finally, I also thank the editors and two anonymous referees for The American Journal of Comparative Law for their comments and suggestions.
}

${ }^{1}$ A.V. Dicey, A Common Citizenship for the English Race, 7 I CONTEMP. REv. 457, 457 ( I897). 
nowadays considered the quintessentially English, a legal scholar whose ideas are inherently tied to English law. ${ }^{2}$ Why would he want a common citizenship with the United States? The bigger puzzle, of course, is the idea itself. What on earth was Dicey thinking?

Admitting that the idea "must of necessity sound startling," he nevertheless sought to show that it was both "practicable," and "wholly good." ${ }^{3}$ To show that, he proposed that "an Act of the Imperial Parliament should make every citizen of the United States, during the continuance of peace between England and America, a British subject, and that simultaneously an Act of Congress should make every British subject, during the continuance of such peace, a citizen of the United States." ${ }^{4} \mathrm{He}$ evidently gave the matter considerable thought, because much of the essay is dedicated to addressing various practical problems that might arise in the context of marriage and divorce, elections and voting, the execution of wills, and much else. Though Dicey stressed that the joint citizenship did not imply national or political unity, ${ }^{5}$ he thought that "[c]ommon citizenship...may well lead to permanent alliance" "between the United States and Britain. And though at that point he focused only on these two countries, Dicey did not rule out the possibility of ultimately "exten[ding] of common civil and political rights throughout the whole of the English-speaking people."7

The reason I mention this historical curiosity is because of the central reason Dicey gave in support of it was the two countries' shared legal tradition. What he wrote sounds, by today's standards, so off-the-wall, that it deserves a lengthy quote:

An English lawyer is the natural advocate of isopolity, for no one can so well appreciate the fundamental identity of English and American law, and all that this identity implies. An English barrister who lands for the first time at New York feels for a moment that he is a stranger in a strange country, the strangeness of which is increased, rather than diminished, by the fact that its inhabitants speak the tongue of England; but when once he enters an American court, or begins debating legal questions with American lawyers, he knows that he is not abroad, but at home; he breathes again the legal atmosphere to which he is accustomed. The law of America, he finds, is the law of England carried across the Atlantic, and little changed even in form. In all legal matters it is the conservatism, not the changeableness, of Americans which astonishes an English observer. Old names and old

${ }^{2}$ See, e.g., Harry W. Jones, The Rule of Law and the Welfare State, 58 CoLuM. L. REv. I43, I49 ("Dicey on the rule of law is...untranslatable, not because his words are English but because the very thought being communicated is inextricably bound up with English institutions").

${ }^{3}$ Dicey, supra note I, at 458.

${ }^{4} \mathrm{Id}$. at 457 .

${ }^{5} \mathrm{Id}$. at $457-58$.

${ }^{6}$ Id. at 472; see also id. at 467 ("common citizenship may well stimulate first co-operation and then alliance").

${ }^{7}$ Id. at $45^{8}$. 
formulas meet us in every law court. Some twenty-six years ago there were to be found in Chicago in daily use forms of pleading which had long become obsolete in England. Nowhere can one discover such choice specimens both of legal learning and of legal conservatism as among the judges or lawyers of Pennsylvania, Vermont or Massachusetts. We may be certain that men like Lord Selborne, Lord Westbury, or Lord Cairns shocked some of the ablest among American lawyers by their zeal for legal improvements or innovations. Then, too, authorities and precedents are cited by Americans, just as they are cited by ourselves, and as they never are cited by any French advocate or magistrate. The names, moreover, which carry weight are the names to which we are accustomed. Coke, Hale, Mansfield, and Blackstone are as well known, and at least as much reverenced, in Massachusetts as in England. Kent and Story, in like manner, are as much respected in an English as in an American court. Nor is the interchange of legal ideas in any sense a matter of the past. The monumental work of my friends Sir F. Pollock and Professor Maitland is studied with as much care and admiration at Harvard as at Cambridge or Oxford. One may confidently assert that the "History of English Law," or Sir William Anson's "Law of Contract," finds more readers in the United States than in England. The writings, on the other hand, of Holmes, Thayer, or of Bigelow, are in the hands of every Englishman interested in the scientific or historical study of law. Nor is the fact that Englishmen and Americans partake of and contribute to a common legal literature, and that the common law of England is the heritage of the whole English race, a matter of which it is possible to overrate the significance. When at some distant period thinkers sum up the results of English as they now sum up the results of Grecian or of Roman civilisation, they will, we may anticipate, hold that its main permanent effect has been the diffusion throughout the whole world of the law of England, together with those notions of freedom, of justice, and of equity to which English law gives embodiment. ${ }^{8}$

\section{Dicey then added:}

Let my readers try to realise the greatness of English achievements in the field of law, for they will then feel that Englishmen in England and Englishmen in America have taken, and are taking, an equal part in the great work of the whole English race, and that their common success in this common effort arises from their possessing the same conceptions of legal order and of legal justice. Here, if anywhere, may be seen community of sentiment and convictions. Common citizenship is the logical, one might almost say the necessary, result of the inheritance of a common law. ${ }^{9}$

Others, even when not going so far as to suggest a joint citizenship, expressed rather similar views about the similarity between English and American law. ${ }^{10}$ Around the

${ }^{8} I d$. at $469-70$.

${ }^{9} I d$. at 47 I. For the historical context of these views see text accompanying notes _, infra.

${ }^{10}$ In England, Frederick Pollock was not far behind Dicey when he wrote (apparently in all seriousness) that "[1]awyers may...regret[] that the hostilities which at one time actually took place between the United States and the French Republic were not prolonged or not serious enough to bring about an Anglo-American alliance." Frederick Pollock, The ExPANSION OF The Common LaW 4-5 (1904); see also James Bryce, The Influence of National Character and Historical Environment on the 
same time Dicey published his essay John Dillon, a prominent American legal scholar and judge, ${ }^{11}$ published a book entitled Law and Jurisprudence of England and America, based on the Storrs Lectures he delivered at Yale. Dicey would have undoubtedly assented to what Dillon had to say about the relationship between English and American law. Again, it is worth quoting him at some length:

The common law affiliates the legal systems of England and the United States, and also the legal system of all of the other States of the Union. It makes them all akin. It gives them an organic character. It is a living bond of union, since it is the cause and medium of a constant and active intercommunication and intercourse, making the people of the whole country neighbors. ${ }^{12}$

Our system of laws and jurisprudence is consonant with the genius of our people and with our civil and political institutions;...it is an outgrowth of them, and powerfully supports and sustains them. It is, in its ground-work, the system that prevails wherever, on either continent, our language is spoken. In our law libraries we find the learning and labors of judges administering this system in law reports from India, South Africa, Australia, New Zealand, the Dominion of Canada, the Sandwich Islands, and the West Indies. All this is the heritage, by what I may call a species of tenancy in common, of the English and American lawyer, who wherever, within this wide horizon, he finds his language spoken, finds also individual and civil liberty, popular institutions, the grand and petit jury, legislative assemblies, Magna Charta, Habeas Corpus, equality before the law, the same sacred regard for individual rights, the same reverential affection for, and instinctive obedience to law. What incalculable advantages! We have the same legal literature. We have the same legal firmament, in which we behold Hale and Marshall, Hardwicke and Story, Blackstone and Kent, Erskine and Webster. We partake freely of the benefits of the labors of each other. Whoever achieves anything for the advancement or improvement of the law, achieves it not for his own country alone, but for all English-speaking and English-governed peoples. ${ }^{13}$

A century later Richard Posner, another prominent American legal scholar and judge, published a book with an almost identical title, based on the Clarendon Lectures he delivered at Oxford. It is replete with comments indicating that the gulf between English and American law is vast. The differences Posner mentioned included the structure of the legal profession, the place of law in society, the prevailing approach to adjudication and the style of judicial opinions, the boldness of the judiciary, the

Development of the Common Law, 24 LAW Q. REV. 9, Io ( I908) ("the Common Law is a common possession of the United States and of England because that spirit and those tendencies and those mental habits which belonged to the English stock when it was still undivided have been preserved until now"). The dying gasps of this view, including a reference to "the law of the English peoples," are found in Roscoe Pound, The Development of American Law and Its Deviation from English Law, 67 Law Q. REv. 49, 65-66 ( 195 I). Pound was eighty at the time.

${ }^{11}$ See John Forrest Dillon, Wikipedia, available at http://en.wikipedia.org/wiki/John_Forrest_Dillon.

${ }^{12}$ John F. Dillon, Law And Jurisprudence of England and AMERica I 56 ( I 894).

${ }^{13} I d$. at $193-94$. 
receptiveness of the legal profession to social science, the prevailing legal philosophy, and more. His conclusion was that the "two legal systems... appear to have diverged considerably since the nineteenth century, let alone the eighteenth." ${ }^{14}$ An earlier and more comprehensive comparative study of English and American law (co-authored by an American and an Englishman) reached similar conclusions. After an extensive examination of the two legal systems, they concluded that they embodied two different "visions of law." 15 They found the differences between the two legal systems so profound that it led them to doubt the idea of universal jurisprudence. Instead, they argued for "jurisprudential relativism," the view that "legal phenomena cannot be understood, and ought not to be studied, apart from the context in which they operate." 16

One indication of the divergence is the degree of interaction between the two jurisdictions. Starting with academic culture, consider the early days of the Law Quarterly Review and the Harvard Law Review, founded within a couple of years of each other. In those early days it was not uncommon to find English legal academics, especially from Oxford, publishing in the Harvard Law Review; and though less frequently (perhaps because Americans soon had a large number of homegrown journals), there were also prominent American jurists publishing in the Law Quarterly Review. Nowadays, not only are Americans conspicuously absent from the pages of the latter just as English scholars are absent from the former, these journals look like they belong to different disciplines.

Turning to teaching materials, Langdell's famous contracts casebook included dozens of English cases; Pollock's tort textbook discussed many American cases, and often urged English courts to adopt novel doctrines found in them. ${ }^{17}$ Such transatlantic cross-references are much rarer today.

Even in the academic study of legal history, where one would not expect to see such a gulf, we see a remarkable (and remarkably similar) divergence between English and American scholars. David Rabban has recently noted that unlike the nineteenth century, when legal historians from both countries shared methods and aims, by the late twentieth century there was a marked divide in the field with

\footnotetext{
${ }^{14}$ Richard A. Posner, LaW and Legal Theory in England AND America io6 ( I996).

15 P.S. Atiyah \& Robert S. Summers, Form and Substance in Anglo-American Law: A Comparative Study of Legal Reasoning, Legal Theory, and Legal Institutions 4 I I-I 5 ( I 987 ); see also POSNER, supra note I4, at 36-37.

${ }^{16}$ Atiyah \& Summers, supra note I5, at 4I9; see also Dan Priel, Is There One Right Answer to the Question of the Nature of Law?, in Philosophical Foundations of The Nature of LaW 322 (Wil Waluchow \& Stefan Sciaraffa eds., 20I2).

17 See Neil Duxbury, Frederick Pollock and the English Legal Tradition 225 (2004). As Duxbury shows, Pollock's books were also frequently cited by contemporaneous American courts. See id. at 225 .
} 
scholarship on both sides of the Atlantic "proceed[ing] on independent tracks." The difference was so pronounced that "to the limited extent that the Americans have even been aware of the recent English legal historians at all, they have often treated their work with bafflement or condescension." 18

This divergence is not just confined to the academic world. As Dicey mentioned, American courts used to cite English cases and scholarship relatively frequently, but rarely do so anymore; ${ }^{19}$ in England, especially in private law, citation of American cases is less common than citation to Canadian and especially Australian cases, even though the pool of available American cases is much larger. ${ }^{20}$

When did this divergence take place? Oliver Wendell Holmes provides some helpful pointers. In the same year Dicey published his essay calling for AngloAmerican citizenship, Holmes delivered the address we now know as The Path of the Law. When he spoke there of the "means of the study" of law, he referred to "a body of reports, of treatises, and of statutes, in this country and in England." ${ }^{21}$ Thirty years later, the very same Holmes, an unabashed Anglophile who once wrote in a letter that "England is my crowd," 22 presented a very different view in one of his famous Supreme Court dissents:

Books written about any branch of the common law treat it as a unit, cite cases from this Court, from the Circuit Courts of Appeal, from the State Courts, from England and the Colonies of England indiscriminately, and criticise them as right or wrong according to the writer's notions of a single theory. It is very hard to resist the impression that there is one august corpus, to understand which clearly is the only task of any Court concerned. If there were such a transcendental body of law outside of any particular State but obligatory within it unless and until changed by statute, the Courts of the United States might be right in using their independent judgment as to what it was. But there is no such body of law. The fallacy and illusion that I think exist consist in supposing that there is this outside thing to be found. Law is a word used with different meanings, but law in the sense in which courts

18 David M. Rabban, Law's History: American Legal Thought and the Transatlantic TuRn TO HISTORY 535 (20I3).

${ }^{19}$ See, e.g., William H. Manz, Citation Practices of the New York Court of Appeals: A Millennium Update, 49 BufF. L. REV. I273, I279 (200I) ("there has been absolutely no interest in contemporary British opinions. The few cited [British] cases are invariably quite old, and are included for historical reasons."); William H. Manz, Citation Practices of the New York Court of Appeals: 1850-1993, 43 BUFF. L. REV. I2 I, I32-33 ( I995) (same); Lawrence M. Friedman et al., State Supreme Courts: A Century of Style and Citation, 33 STAN. L. REv. 773, 799 (I98I) ("In I870-I900 a foreign (primarily English) case was cited in only I $5.3 \%$ of [state supreme court] cases;... in I940-I970 there were none.”).

${ }^{20}$ See Peter Clinch, The Use of Authority: Citation Patterns in the English Courts, 46 J. Documentation 287,298 (1990) (American cases were cited only in $0.5 \%$ of cases).

${ }^{21}$ O.W. Holmes, The Path of the Law, Io HaRv. L. REv. 457, 457 ( I 897).

${ }^{22}$ Letter from Oliver Wendell Holmes to Lewis Einstein, Oct. I2, I9I4, in THE Holmes-Einstein Letters: Correspondence of Mr. Justice Holmes and Lewis Einstein, i903-i935, at ioo, ioo (James Bishop Peabody ed., I964). 
speak of it today does not exist without some definite authority behind it. The common law so far as it is enforced in a State, whether called common law or not, is not the common law generally but the law of that State existing by the authority of that State without regard to what it may have been in England or anywhere else... Whether and how far and in what sense a rule shall be adopted whether called common law or Kentucky law is for the State alone to decide. ${ }^{23}$

A decade later, these words were adopted by a majority of the Supreme Court in the landmark case of Erie Railroad Co. v. Tompkins. ${ }^{24}$

Legislation provides another illustration of a similar shift, taking place within a similar timeframe. The Uniform Sales Act of I 906 was modeled on the British Sale of Goods Act of I 893. Less than half a century later, the Uniform Commercial Code was conceived as a wholly American creation. It adopted a novel terminology and made no effort to retain any strong links with the commercial law of the rest of the common law world. The old guard criticized this change, ${ }^{25}$ but by then this seemed like a quaint concern. (Karl Llewellyn played a central role in the formulation of the Code, especially of Article 2 that deals with sales. This, as we shall see, is not insignificant.)

Historical processes rarely begin or end abruptly, but these events provide convenient temporal boundaries for the inquiry. It was sometime in the period between I935 and I945 that the two legal systems drifted apart. With this rough timeframe, the puzzle this essay seeks to explain can be presented as follows: Why is it that two legal systems sharing one historical origin and which early in the twentieth century were thought to be close enough to merit considering joint citizenship, diverged so quickly? At first sight the timing of the change lends itself to a ready answer: legal realism. ${ }^{26}$ The familiar story is that it radically and irrevocably changed the way Americans thought about law; English lawyers, however, remained at best indifferent to its charms. ${ }^{27}$ After the realist revolution Americans no longer saw any

${ }^{23}$ Black \& White Taxicab Co. v Brown \& Yellow Taxicab Co., 276 U.S. 5I 8, 533-34 (I 928) (Holmes J., dissenting). In Holmes's mind this conception of authority was connected to the physical limits of political power. See American Banana Co. v. United Fruit Co., 2 I 3 U.S. 347, 356-57 ( I 909).

${ }^{24} 304$ U.S. 64, 79 ( I938).

${ }^{25}$ See Samuel Williston, The Law of Sales in the Proposed Uniform Commercial Code, 63 HARV. L. REv. 56I, 564 (1950) ("When the American [Sales] Act was drafted it was thought to be of considerable advantage that the statute so closely resembled the English statute....It is surprising, when the scope of the world is now narrowed by increased speed of transportation...that the advantage of similarity to the English law should be so lightly cast aside.”).

${ }^{26}$ This answer is suggested, for example, in Robert Stevens, Basic Concepts and Current Differences in English and American Law, 6 J. LEGAL HIST. 336, 344 ( I 985 ).

${ }^{27}$ This attitude is best captured in the quip: "It was perhaps appropriate that the age of jazz should produce a Jazz Jurisprudence.” C.K. Allen, LaW IN THE MAKING 45 (3d ed. I939). For more on the generally unsympathetic attitude to legal realism in England see Neil Duxbury, English Jurisprudence Between Austin and Hart, 9I VA. L. REV. I, I3, 54-6I (2005). To his credit, Allen removed this description 
real possibility for a meaningful interaction with antediluvian English lawyers, ${ }^{28}$ while many English lawyers thought of the developments wrought by legal realism as antithetical to the very idea of law, ${ }^{29}$ and were therefore uninterested in borrowing from American law.

As we shall see, there is some truth to this familiar story, but it is unsatisfactory for two reasons. First, by itself it does not go deep enough, for it immediately raises the question, "Why were English lawyers so hostile to realist ideas?" Despite some interest in realist ideas in certain quarters ${ }^{30}$ legal realism took a long time to make headway in England (some would say, it has yet to do that). Why is that? I will not attempt to answer this question here, but the argument I will proffer in this essay, if successful, goes some way toward answering it. Second, I hope to show that even as it stands the explanation is insufficiently nuanced. In the typical story legal realism is contrasted with legal formalism, and accordingly American law is treated as realistic while English law is portrayed as formalistic. ${ }^{31}$ One aim of this essay is to explain why this distinction is too crude to be of explanatory value. I will argue that it tends to conflate different views that are best kept separate. ${ }^{32}$

To do that, my argument seeks to identify deeper, and older, differences between English and American common law, which in turn will both help to explain the different fates of legal realism in the two countries and also their present divergence. I will argue that the parting of ways reflects a difference in the prevailing political

from later editions of the book, and has in fact quite revised his judgment: "Realists...approach all settled and traditional doctrines of the law in a spirit of scepticism. Provided that it does not run to mere showy eccentricity posing as 'originality', or degenerate into dissent merely for bravado...scepticism is no unhealthy frame of mind for the jurist..." C.K. ALLEN, LAW IN THE MAKING 44 (7th ed. I964) [hereinafter ALLEN, LAW]. He further added that "[g]rown out of its youthful exuberances and disabused of its hasty conclusion that law is to be found only in facts and deeds, [the realist] movement brings to modern jurisprudence a spirit of vigilance and exploration which is capable in the right hands of contributing substantially to the understand of law not as a bloodless abstraction but as a living force in society." Id. at 48 .

28 See Richard A. Cosgrove, Our Lady the Common Law: An Anglo-American Legal Community, i 870-I930, at 280-83 ( I987).

${ }^{29}$ See, e.g., Peter Birks, Equity in the Modern Law: An Exercise in Taxonomy, 26 U.W. AusTL. L. Rev. I, 98 ( I996).

${ }^{30}$ See Cyril Glasser, Radicals and Refugees: The Foundation of the Modern Law Review and English Legal Scholarship, 50 MOD. L. REV. 688, 696-704 (I987); see also Duxbury, supra note 27, at 62-69.

${ }^{31}$ See ATiYaH \& Summers, supra note I5, at 4io; Stevens, supra note 26, at 343-44.

${ }^{32}$ In this I sharply disagree with a position recently presented in BRIAN Z. TAMANAHA, BEYOND THE Formalist-Realist Divide: The Role of Politics In Judging (20 Io). While Tamanaha too criticizes the distinction between realism and formalism, he seeks to replace it with a single, middle-of-the-road "balanced realism." See id. at 6-7, I8I-99. My view, by contrast, is that the formalist-realist divide is faulty because it is insufficiently nuanced. 
ideologies in the two countries. These different ideologies manifest themselves in two distinct understandings of the authority of the common law, which in turn explain the respective attitudes in these countries to what I will call "common law commonality," i.e. to the idea that the common law reflects some a kind of supranational law to which all common law jurisdictions are joint contributors.

Here is how my argument proceeds. I begin by distinguishing between four different conceptions or models of the authority of the common law. I will argue that these different conceptions reflect different underlying philosophies for what makes common law rules binding. Though these different conceptions may seem abstract and "academic," I argue that they imply different answers to the question of common law commonality. I then return to English and American law and argue that the decline in their commonality is explained by the fact that their underlying accounts of commonality are different as a result of the two countries' different political traditions.

Before proceeding, let me add one important caveat. I believe that the account offered here provides an important ingredient to understanding that elusive entity known as "the common law," as well as the puzzle of the divergence between English and American law. I do not claim that it provides a complete explanation. Any complex social phenomenon or change is the product of numerous factors working together. There are other possible explanations for these phenomena, and it is wellnigh impossible to identify their relative contribution. ${ }^{33}$ My claim, then, is not that the argument presented here exclusively explains Anglo-American divergences; only that it is one important piece in the puzzle.

\section{Four Philosophies of the Authority of the Common Law}

When talking about the common law some writers become misty-eyed, referring to it as if it were some mythical entity with a life of its own. ${ }^{34}$ But to a large extent the

\footnotetext{
${ }^{33}$ See note 139 infra, where I consider the possible relationship between my account and alternative explanations.

${ }^{34}$ See, e.g., Frederick Pollock, The Genius of the Common Law 2 (I9I2) ("We are here to do homage to our lady the Common Law....Her soul is founded in an order older than the gods themselves, but the joy of strife is not strange to her, nor yet the humours of the crowd. She belongs to the kindred of Homer's gods, more powerful than men but not passionless or infallible."); Roscoe Pound, What Is the Common Law?, 4 U. CHI. L. REv. I76, I78-79 ( 1937) ("The materials of an Anglo-American law library are increasingly heterogeneous....Yet, when we examine these phenomena more closely, we do seem to see something universal, permanent, enduring, behind them; something binding our administration of justice to that of England and Ireland and Canada and Australia; something binding our administration of justice not merely to that of Blackstone's time not merely to the classical common-law era, the time of Sir Edward Coke, but even to the medieval English law....This something we call the common law.”).
} 
common law is nothing but a record of the reasons provided by a bunch of peoplemost of whom left no discernable mark on the history of thought—in the course of deciding disputes. To the extent that the common law is used as a source of legal norms, we should try to evaluate how well it performs this function. More concretely, in justifying it we should be concerned with two related questions: First, is (and, when is) the common law method a good way for generating legal norms? And second, what is the basis for the authority of judges deciding cases and (thereby) generating legal norms? These questions are clearly connected, for an affirmative answer to the first question will probably go some way toward furnishing an answer to the second. Nevertheless, they are distinct: One may think common law norms can be authoritative even if judges are not exceptionally good norm creators, or vice versa. Furthermore, the question of judges' authority arises even if one thinks judges should not (normally) create legal norms. Judges have authority in deciding disputes between individuals, even if in doing so they are merely following rules, and that power too requires justification.

In what follows I address directly only the second of the two questions. I do so by presenting four competing accounts of the authority law and their applicability to the common law. In each case I present an ideal-type, a philosophical construct in something close to its pure form. The reality of the common law, the product of the efforts of many, is never similar to the ideal-types I present here. Within one jurisdiction one can find different commentators (be they judges, lawyers, or legal scholars) who express different views on the authority of the common law. And as we shall, different ideal-types can sometimes be combined to create hybrid accounts.

Nevertheless, the seemingly abstract theoretical discussion of these ideal-types is valuable because different understandings of the authority of the common law often lead to different practices, including the question that lies at the heart of this essay, that of common law commonality. And though the ideal-types are not found anywhere, different legal systems will tend to manifest certain conceptions more than others. Thus, if we imagine the four ideal-types as four points forming a square representing the possible theoretical landscape, different legal systems could be placed in different positions within that square according to how much they reflect a commitment to a particular conception. As I will try to show these differences will not typically be random. Whenever differences in the ideal-type imply differences in the practice, the latter will tend to reflect a particular ideal-type.

Though such statements are perhaps less common these days, they are far from gone. See, e.g., ANDREW Burrows, Understanding the LaW of Obligations: Essays on Contract, Tort and RESTITUTION I36 (I998) ("I have too much faith in the judiciary, and too much love of the deductive technique of common law development to wish to see the law frozen by widespread legislative intervention"); cf. David A. Strauss, The Living Constitution 40 (20io) ("The common law is...governed by a set of attitudes: attitudes of humility and cautious empiricism”). 
When applied to the question of common law commonality, the four ideal-types lead to different answers to this question ranging from universal (i.e., not just common law) commonality to a complete rejection of commonality. Armed with this analytical framework, I will return in the next section to the question with which this essay began, namely the different attitudes in English and American law to the idea of common law divergence.

\section{(a) Reason}

Reason as an ideal-type may be likened to one familiar conception of natural law. Though the term "natural law" has been used to describe numerous quite different ideas (at least one other sense will be discussed below), here I refer to a fairly specific sense of the term, which seeks to explain the question of the authority of the common law as an instance of the idea of the inherent authority of practical reason. In this understanding, law is the product of, and discoverable by, a priori reflection on about humans, their nature and capacities, and the kind of "juridical relationship" they find themselves in.

This view has several characteristics: First, the view is very top-down in the sense that its proponents tend to think that one can derive, more-or-less deductively, answers to specific questions from a small number of general, a priori principles that govern whole areas of law (for example, the whole of tort law, perhaps even the whole of private law). Second, proponents of this view tend to insist on a strict separation between law and politics and on a parallel distinction between private and public law. Law "proper" is private law, and it is completely separate from politics, because it is the product of reason. Public law is the product of political machinations, and as such can hardly be said to be derived from reason (and, some would say, can hardly be called "law"). That is why proponents of this view are adamant that "policy" is the antithesis of pure reason and as such inappropriate for private law. Third, as reason is unchanging, the norms of private law are (largely) constant, regardless of time and place; for those who hold this view, the norms in question are not a particular political community's attempt to "arrange and rearrange the legal landscape in response to pressures operative within the organism of social life." 35

The common law has an ambivalent role in the works of proponents of this view. On the one hand, the historical association of the common law with contract, tort, and property lends itself to the reproducing the law/politics divide to correspond with the distinction between common law and statute law. (Proponents of this view tend to silently pass over the fact that other areas of law such criminal law and family law also have their origins in judge-made common law.) The distinction between common law

35 Ernest J. Weinrib, The Idea of Private LaW i4 (new ed. 20I2); see also Allan Beever, Forgotten Justice: The Forms of Justice in the History of Legal and Political Theory 20405 (2013). 
and statute is transformed into the different distinction between private law (the product of pure reason) and public law (which, despite its legal form, is the product of political processes).

At the same time, however, one of the striking aspects of this view is its utter disregard to the common law as a theory of authority. The common law is a useful category as it carves the domain of private law. But beyond this, the common law as a distinct form of authority, as a particular way of finding the right answers to legal questions, is completely discounted: "When asked a difficult question, the common lawyer, if she is a modern, thinks either of cases or statutes and, if she is a traditionalist, ponders principles and ideas." ${ }^{36}$ What the author of this statement calls "traditionalism" is the rationalist view under consideration. It is marked by little regard to court decisions, typically picking a small number of paradigm cases that they use to illustrate ideas their validity they derive from elsewhere. To most contemporary proponents of this view, the main source of inspiration is the philosophy of Immanuel Kant, not the history of the common law.

Though this view has some following in academic circles, it has had relatively little influence on the development of the common law. ${ }^{37}$ Early in the nineteenth century it had some influence among American writers, ${ }^{38}$ but it was largely by writers influenced by civil law and who have urged common lawyers to adopt its methods. ${ }^{39}$ These days this approach owes its relative success in the legal academy to the

${ }^{36} I d$. at 206. To see the similarity between this view and civilian thinking, compare R.W. Lee, The Law of Blasphemy, I6 MiCH. L. REV. I49, I56 ( I9I8) ("In civil law jurisdictions the decision of the courts are said to be determined by the authority of reason rather than by reason of authority").

${ }^{37}$ Natural law thinking is not absent from the common law. Nevertheless, it is notable that often references to natural law by common law writers were often nothing more than "veneer." D.J. Ibbetson, Natural Law and Common Law, 5 Edinburgh L. Rev. 4, I2 (200I). Even when given a more constructive role in providing doctrinal ideas or structure for various areas of law, it is rare to find the law-as-reason conception of natural law in the history of the common law. Blackstone, for example, has always combined ideas derived from natural law thinking with a custom-based theory of authority. See MICHAEL

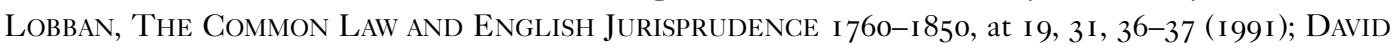
Lieberman, The Province of Legislation Determined: Legal Theory in Eighteenth CENTURY BRITAIN 37-45 (I990). His references to natural law were consistent with scholarly assumption at the time, but were not used to derived specific conclusions in a manner similar to a reason-based account of the law. See id. at 46.

38 See A.W.B. Simpson, The Rise and Fall of the Legal Treatise: Legal Principles and the Forms of Legal Literature, 48 U. CHI. L. REv. 632, 672-73 (I98I). Even then these ideas were often mixed with others. See Bernadette Meyler, Towards a Common Law Originalism, 59 STAN. L. REV. 55 I, 580-8I (2006).

${ }^{39}$ See M.H. Hoeflich, Law \&̊ Geometry: Legal Science from Leibniz to Landgell, 30 AM. J. LEGAL HIST. 95, I I2-I 5 (I986). It is often thought that Langdell represented this view as well, but I think the place he gave to cases in the derivation of law's principles suggests a different approach. See note I50 infra, and accompanying text. 
influence of professional moral philosophy in law schools, rather than to anything found in legal practice itself. In the English-speaking world its most prominent proponent is Ernest Weinrib. In his writings Weinrib drew an explicit link between his view and a particular conception of natural law when he said that "[i]nasmuch as [legal forms] are immanent to the juridical relationship they inform, they shed light on the traditional claim of natural law theory that law is an ordering of reason." ${ }^{40}$

Despite its defenders' claims to being committed to explaining the law "from within," ${ }^{41}$ the reality is that it thrives on the gap between academic law and legal practice. Nevertheless, in part for completeness's sake, in part because of the presence of this view in contemporary literature, it is worth exploring briefly its attitude towards commonality. As just mentioned, proponents of this view do not much care for the common law and its history, drawing their ideas from Kant and other non-consequentialist moral philosophers. That Kant had virtually no influence on the development of the common law is, for them, entirely irrelevant. What matters is what pure practical reason requires and that is not something about which geography or history have much to say.

It follows from this perspective that the common law is not just ignored as exemplifying a theory of authority, but also as an important jurisdictional divide. Indeed, the centrality of reason as a foundation of law can itself be seen as a borrowing from civilian legal systems, where the idea has played a much more prominent role. ${ }^{42}$ The kind of natural law that these scholars see as providing the basis for the authority of the common law exists is universal. The way one ought to behave according to reason is equally available to all humans who have the capacity to reason, i.e. to all humans, wherever and whenever they are. No doubt what one ought to do in particular circumstances may be affected by those circumstances, but reason itself remains unchanging, and so are the general rules it prescribes. ${ }^{43}$ On this view

${ }^{40}$ Ernest J. Weinrib, Why Legal Formalism, in Natural Law Theory: CONTEMPORARY Essays 34I, 34I (Robert P. George ed., I992); see also Allan Beever, The Declaratory Theory of Law, 33 OxfORD J. LEGAL STUD. 42 I, 428-29 (2013).

${ }^{41}$ See WeINRIB, supra note 35 , at i 8 (arguing that private law is "immanently intelligible"); ALLAN BeEver, Rediscovering the LaW OF Negligence 34-36 (2007) (defending an "internal" analysis of law). For a critique of the supposed internality of this approach see Dan Priel, Land Use Priorities and the Law of Nuisance, 39 MELB. U. L. REV. 346, 360-65 (20 I 5).

42 See H. Patrick Glenn, Legal Traditions of the World: Sustainable Diversity in Law I5 I-55 (4th ed. 2008); Franz Wiacker, A History of Private LaW in Europe 257-75 (Tony Weir trans., I 995) (2d ed. I967). It is notable that reference to custom was forbidden in some law-as-reason natural law codes. See id. at 268.

${ }^{43}$ See Allan Beever, How to Have a Common Private Law: The Presuppositions of Legal Conversation, in The Common Law of Obligations: Divergence and Unity 215, 227-28 (Andrew Robertson \& Michael Tilbury eds., 20I6) [hereinafter Divergence AND UNITY] (arguing that all common law 
the authority of the common law does not derive from anything in the common law itself, but from whether it matches the pre-existing norms of natural law discovered with the aid of reason. Whether a given legal system succeeds in matching this natural law is a contingent fact.

Despite some academic following, such ideas, especially in anything resembling their pure form, are rare in contemporary common law practice. ${ }^{44}$ With the central place it accords to history, the common law is not a hospitable ground for such an approach. A variant on this view may be thought to have had greater success. This view seeks to merge civilian thinking with respect to the common law tradition with its focus on cases. The prominent English academic Peter Birks is probably the best exponent of this approach. Though Birks was not particularly interested in the work of Kant or that of his present-day followers, his works convey a clear affinity, one that intensified over the years, with Roman law and its contemporary civilian descendants. ${ }^{45}$ Given the common law's attachment to history as a source of authority, Birks's strategy of unearthing the Roman law influences on the development of the common law may be seen as an attempt to incorporating civilian thinking into the common law on the basis of acceptable common law methods.

The effect was that like his more philosophical counterparts, Birks was largely indifferent to the common law/civil law divide, borrowing freely (some would say exorbitantly) from civilian legal systems and scholars, both in terms of modes of thought and in terms of substantive ideas. Furthermore, his thinking reflected the rationalist approach in the way he sought to defend the basis of legal liability. Perhaps the most striking example of this attitude is his defense of the fundamental principle of unjust enrichment. The existence of this principle was not for Birks a matter to be derived from the cases. It was a part of reality, one that anyone who will put his mind to the matter will recognize. A legal system that did not have a law of unjust enrichment acknowledged as an independent legal category was deficient, even if it reached the right outcomes: "It displaces the truth. And it introduces a lie." ${ }^{46}$ It is

jurisdictions aim at "an objective truth" and they all "aim at the same thing," which is why divergence does not imply differences in local circumstances, but that at least one jurisdiction "must be wrong").

${ }^{44}$ This is not merely my assessment. This is admitted by proponents of this view. See, e.g., BEEver, supra note 36 , at 243 (lamenting the fact that the prevailing views on law pose "an enormous obstacle standing in the way of our understanding of our law"); Ernest J. Weinrib, Does Tort Law Have a Future?, 34 VAL. U. L. REV. 56I (2000) (criticizing courts for departing from his preferred views).

45 On Birks's devotion to Roman law see Gerald McMell, What Kind of Jurist Was Peter Birks?, I9 Restitution L. Rev. I5, 20-2 I, 22-23 (20 I I); Lionel Smith, Peter Birks and Comparative Law, 43 Revue De Droit de L'Université De Sherbrooke i93, I98-203 (2013), although Smith attributes to Birks the claim that "each tradition must develop according to its own genius," $i d$. at I98, which I think is not an accurate description of Birks's view.

${ }^{46}$ Peter Birks, An Introduction to the Law of Restitution 22 (rev. ed. i989). 
clear from such statements that for Birks, legal truth was independent of what one found in the cases. But if one were to wonder what constituted that legal truth, Birks had surprisingly little to say on the matter. Ultimately, the justification of first principles derived from its indubitable rational appeal. ${ }^{47}$

As Birks is widely considered to have been one of the most influential English legal academics of the last century, his commitment to this view of the common law might be used to counter my claim that the reason-based conception of the authority of the common law has little support. Though Birks's influence is undeniable, in his efforts to convert other common lawyers to civilian ways of thinking, ${ }^{48}$ have met with little success. ${ }^{49}$

\section{(b) Practice}

In terms of its impact on common law thinking, what I will call the "practice conception of authority," has been far more significant. Unlike the previous view that sees the basis of law's authority in "natural reason," this view sees the common law's authority as somehow derived from the law's "artificial reason." The law's reason is not something available "naturally" to all individuals; rather it requires special expertise and erudition in legal materials, as it is the product of working out of the law from a mass of legal materials. These materials are not strictly speaking the law, but it is through careful consideration and interpretation of these materials that one derives the law from them.

47 See Peter Birks, Unjust Enrichment 6-8 (2d ed. 2005) (the justification of the basic principle of unjust enrichment is its self-evidence, regardless of what courts say). Contrast this with ANDREW Burrows, THE LAW OF RESTITUTION 4 (3d ed. 20 I I) (the ultimate justification of the law of restitution is to be found in the cases).

48 See Peter B.H. Birks, More Logic and Less Experience: The Difference Between Scots Law and English Law, in The Givilian Tradition and Scots Law: Aberdeen Quincentenary Essays i67 (David L. Carey Mill \& Reinhard Zimmermann eds., I 997) [hereinafter Birks, More Logic]; Peter Birks, This Heap of Good Learning: The Jurist in the Common Law Tradition, in Law Making, Law FINDING, AND LaW SHaPING I 3 (Basil Markesinis ed., I997) [hereinafter LAW MAKING].

49 Birks was the subject of a thinly-veiled attack in the Australian High Court's decision in Roxborough v. Rothmans of Pall Mall Australia Ltd., [200I] HCA 68, 208 C.L.R. 5I6, at [70]-[89]. Justice Gummow captured in it the difference between Birks's reason approach and the practice-based approach I discuss below: "To the lawyer whose mind has been moulded by civilian influences, the theory may come first, and the source of the theory may be the writing of jurists not the decisions of judges. However, that is not the way in which a system based on case law develops; over time, general principle is derived from judicial decisions upon particular instances, not the other way around." Roxborough, supra, at [72]. Burrows expressed puzzlement at this criticism in Andrew Burrows, The Australian Law of Restitution: Has the High Court Lost Its Way?, in Exploring Private LaW 67, 73-74 (Elise Bant \& Matthew Harding eds., 2010). But the critique is accurate. Burrows's puzzlement reflects the fact that his own writings are founded on the practice-based approach. 
In some respects this is still a dominant, perhaps the dominant, view among common lawyers in the Commonwealth. It is often depicted with the image of the "blackletter lawyer," who knows all the cases, and believes that answers to new legal questions can and should be derived from analyzing them. Here, the law's authority is the product of "long study and experience" 50 of legal materials acquired by a small cadre of legal experts, not the natural reason that is available to any person who puts her mind to the matter. A defender of the practice view does not see herself as having to look for a justification of the decisions any source external to the legal decisions; it is the law that furnishes its own justification. This approach is often seen by its critics (and, admittedly, by some of its supporters) as an example of the (English) lawyer's anti-intellectualism. ("Jurisprudence," Dicey once wrote, "is a word that stinks in the nostrils of the practising barrister." ${ }^{51}$ ) But professing a lack of interest in philosophy does not mean not having one. As Keynes once famously remarked, "Practical men, who believe themselves to be quite exempt from any intellectual influences, are usually the slaves of some defunct economist." ${ }^{2}$

Or a defunct philosopher. Anthony Quinton identified what he thought were the three central principles of conservatism: First, "traditionalism," namely "attachment to, or reverence for, established customs and institutions," and "hostility to sudden, precipitate...change." Second, "organicism, which takes a society to be a unitary, natural growth, an organized, living whole, not a mechanical aggregate." And third, "political scepticism, the belief that political wisdom, the kind of knowledge that is needed for the successful management of human affairs, is not to be found in the theoretical speculations of isolated thinkers but in the historically accumulated social experience of the community as a whole." 53 It does not take much to see the similarity between this and the practice conception of the common law. (If any change is needed it is in transferring the ideas about the organicism of society to the "seamless web" of the common law.) Edmund Burke, with whom this conception of conservatism is most frequently associated, has himself drawn a link between his political ideas and the common law method as explicated by the likes of Edward

${ }^{50}$ Prohibitions del Roy, (I607) I2 Co. Rep. 63, 65, 77 Eng. Rep. I342, I343 (K.B.). Coke famously contrasted natural and artificial reason and argued that legal cases are governed by the latter. See id. There is a clear gap between this view and the natural reason view, which considers reason available to all humans.

${ }^{51}$ A.V. Dicey, The Study of Jurisprudence, 5 LAw MAG. \& REV. (4th ser.) 382, 382 ( I880).

52 John Maynard Keynes, a General Theory of Employment, Interest, and Money 383 ( I936).

53 Anthony Quinton, The Politics of ImPerfection: The Religious and Secular Traditions of Conservative Thought in England From Hooker to OAKeshotT i6-I 7 ( I978). 
Coke and Matthew Hale. ${ }^{54}$ Operating on the basis of limited information in the course of resolving particular cases, this approach seeks to work out a "philosophy," albeit always a provisional one, that emerges from narrow "common sense" responses to concrete incidents rather than as a derivation from a grand overarching philosophy. ${ }^{55}$

Notice that the relevant community for such practices is not the general public. The custom in question refers to an accepted view among the community of lawyers. It is "judicial opinions" which are "the principal and most authoritative evidence, that can be given, of the existence of such a custom as shall form a part of the common law," said Blackstone. ${ }^{56}$ This approach thus has another "Burkean" characteristic: The common law is an anti-democratic, perhaps even aristocratic affair.

The obverse of this view is the view that appeals to abstract discussions in moral philosophy, social history, economics, or any other discipline outside the law as justification for legal rules are misguided. A proponent of this view will not deny that prevailing ideas outside the law have an impact on the development of the law, but to the extent that they do, those are already incorporated, often unconsciously, into legal materials. Thus, unlike the natural reason view, the practice view allows some reliance on "public policy," though insists that it is nothing more than "a body of rules in some cases fixed, in other cases flexible, but governed by precedent and authority like other branches of the common law." ${ }^{57}$ Appeals to policy are neither an invitation for lawyers to frame grand theories about the law, nor a place to introduce alien disciplines into the law.

This form of "internality" is most significant in the way it seeks to explain not just the sources of the common law but its authority. On the practice-based view the most fundamental error of the other approaches to the common law's authority is that they seek to justify the law by appeal to other disciplines. Unlike the natural reason view which claims to be internal to the law but sees law as justified to the extent that it matches the precepts of pure practical reason (which are external to the law), defenders of the practice view take seriously the idea that justifying the law involves the ability to reconstruct a successful argument in support of a legal conclusion from existing legal materials. A justified legal argument is the most compelling argument

\footnotetext{
${ }^{54}$ See J.G.A. Pocock, Burke and the Ancient Constitution-A Problem in the History of Ideas, 3 HIST. J. I25, I 28-3 I, I37-38 (I960). Pocock in fact finds Burke more open to ideas coming to law from the outside than the common lawyers, for whom all ideas had to come from "within" the law. See id. at I39.

55 See John Laws, The Common Law Constitution 7-9 (20 I4); Strauss, supra note 34, at 40-42.

${ }^{56}$ William Blackstone, i Commentaries *69.

${ }^{57}$ Lord Wright, Public Policy, in Legal Essays AND AdDREsSEs 66, 95 ( I939). Additional examples of this view are found in Michael Lobban, English Jurisprudence and Tort Theory, in THE IMPACT OF IDEAS ON Legal Development I 27, I33-34 (Michael Lobban \& Julia Moses eds., 20 I2).
} 
one can construct on the basis of existing legal materials. Law on this view does not have any master but itself.

The idea here is not that previous legal decisions have authority merely because they took place in the past. Rather, the idea is that traditions have authority, and that novel decisions ought to be justified as part of a tradition, by showing how they fit within a pattern of past decisions. To those who accept this view, traditions have authority, because history is the repository of a great deal of slowly accumulated knowledge that accumulates to a kind of communal wisdom. That is why the common law can have authority even though it is just, to use the phrase I used earlier, "a record of the reasons provided by a bunch of people-most of whom left no discernable mark on the history of thought-in the course of deciding disputes": it reflects the combined efforts of the ages, and as such is wiser than each individual on his or her own.

The authority of the past is thus tied to a certain implicit epistemological theory. But it is not simply the view that we should appeal to the wisdom of crowds. Another central component of this view focuses on the uncertainty inherent with making changes to any complex system. In the choice between the familiar and the novel, we should favor the former as it is the devil we know. Large scale changes are bound to have unexpected and unpredictable consequences, which is why they are almost always likely to be changes for the worse. On the other hand, the incremental developments sanctioned by this view appear to be mere commonsensical extensions of the accepted and familiar (using analogies and other seemingly neutral tools of thought). The normativity of social institutions is thus inherently a communal, distributed, effort, the product of the joint efforts of many minds (both living and dead). This view thus stands in sharp contrast to the reason-based conception, which asserts that any single individual can, by the application of pure reason, identify correct moral principles.

Properly understood, then, the claim is not that the content of law is what it used to be in some ancient point in the past. It sees history as a source of authority, not (or not in any simple way) as a source of law's content. One should seek the "true" or "original" understanding of law in some ancient texts, because they are somehow purer or the people who wrote them wiser. The idea is rather that what gives law today its normative force, its authority, is the fact that it has been derived from past law through a process of working and reworking of solutions from existing materials. It is therefore no challenge to this view that the law today is different from what it used to be. On the contrary, this view acknowledges the possibility, even the inevitability, of legal change. Indeed, the skepticism of universal truths and the commitment to the normative significance of history that is central to this view imply that what ought to be done now may be different from what had to be done in the past. Moreover, unlike the reason-based view, which sees an unbridgeable chasm 
between what people do (which is wholly in the domain of the "is") and what they should do (which belongs to the wholly separate domain of "ought"), the practicebased view insists that what the law ought to be is in some sense dependent on what law is, and what law is is in some sense dependent on what it used to be. That, on the practice view, is precisely what we see in common law adjudication. The seemingly anti-theoretical, non-ideological nature of this approach-its explicit rejection of all grand ideas (except, perhaps, for the grand idea that there are no grand ideas) - and its tendency to justify ideas by the fact that "we did so in the past," are all familiar features of the common law.

It is these ideas that explain the reason and the manner with which this approach seeks to keep the common law separate from politics: Not in terms of the strict separation between law and politics that proponents of the natural reason approach insist upon. Proponents of the practice-based view acknowledge that major drifts in the zeitgeist have impact on the law; but this view maintains that when lawyers are seeking justification in past cases, they are engaged in an activity that is relatively free from transient political changes and as such stands largely outside the domain of democracy. ${ }^{58}$ Law on this view is a technocratic affair, the product of almost bureaucratic expertise, not of deep philosophical reflection. ${ }^{59}$ It is for this reason that the legislature should largely stay out of the common law; for legislators lack the requisite kind of expertise and knowledge in the history of law that should guide its future development. Even when legislative reforms do happen, the real work should be left to "expert" practice-based lawyers, not to politicians. ${ }^{60}$

In a clear statement of this view Andrew Burrows has called for "law to be treated essentially as an autonomous discipline." ${ }^{61}$ In this autonomous conception legal scholars (working in close proximity with members of the elite guild known as "the bar"), ${ }^{62}$ work by "analys[ing] carefully the latest reported decisions" and improve the law by "ensur[ing] consistency and rationality in decision-making." ${ }^{63}$ Burrows does not think the common law should be used for "the introduction of new social policies"; ${ }^{64}$ rather it should be used for the development of existing rules (i.e.,

58 See Burrows, supra note 34, at I22; Robert Stevens, Torts And Rights 3i8-I9, 324, 332 (2007)

${ }^{59}$ See, e.g., id. at 307 ("The law of torts is much more boring than is commonly supposed"); id. at 329 (explicitly rejecting appeal to the philosophy of Kant and Hegel for understanding or justifying tort law).

${ }^{60}$ See id. at 3 I 9 ; Burrows, supra note 34 , at I 36.

${ }^{61} \mathrm{Id}$. at $\mathrm{I} \mathrm{I} 3$.

${ }^{62}$ See id. at I I 2 .

${ }^{63} \mathrm{Id}$.

${ }^{64}$ Id. The right tools for solving "difficult practical problems" are, accordingly, "precision in analysis and language." Id. Though Burrows declares himself fascinated with theoretical inquiries, he seems to think of "deep theory," $i d$. at I I 4, as a kind of academic parlor game. It may be an amusing pastime, but 
existing social policies). In this respect, Burrows does not deny that political values enter into the law, claiming even that the law should be based on "shared political and moral values in society." ${ }^{5}$ And yet, echoing the Burkean, anti-democratic vision of the common law, Burrows makes clear that "contract, tort and restitution rest on fundamental long-term values that, while evolving and adapting to new conditions over the course of time, and while influenced by long-term policies, should be immune from short-term party politics." ${ }_{66}^{6}$ Burrows's preference for an autonomous discipline of law guarantees that the source of information about those political and moral values would only be their expression in the legal materials that he thinks are the main (perhaps only) sources that the legal scholar should engage in.

Despite the centrality of this conception of the common law's authority, this view is (with one very important, partial, exception) alien to the dominant discourse in contemporary jurisprudence, because contemporary jurisprudence does not take the common law seriously. ${ }^{67}$ It treats the common law as a series of rules that happen to have been generated by courts, but could just as well have been produced by a legislature. In contemporary jurisprudence which reduces law to a set of rules, this difference in the mode of promulgation is seen as having little normative significance. The only thing that matters for philosophical analysis of law is the content of the rules. Consequently, in the apparent divide between "legal positivism" and "natural law" both views take the justification of law to be the product of its congruence with pre-existing moral standards. To put this point slightly differently, though most legal philosophers embrace the idea that understanding the practice of law should requires adopting the "internal point of view" of legal practitioners, the very same scholars (implicitly) reject the idea that the justification of law should be internal to law. The prevailing jurisprudential view is that internal justification is part of what lawyers do, that this is how one plays the legal game; yet, the dominant view is that law is

it has no practical relevance. See id. at I I9 (warning of the "danger of the next generation of restitutionscholars crossing the line from practical to impractical scholarship").

${ }^{65} \mathrm{Id}$. at I $\mathrm{I} 2$.

${ }^{66} \mathrm{Id}$; ; see also id. at I I0-I I (nineteenth century common law was influenced by laissez-faire).

${ }^{67}$ Ronald Dworkin is the exception, someone who sees understanding and justification of law as continuous activities and therefore insists that both should be internal to the practice. Because of his divergence on this fundamental point from almost all other legal theorists, there has been a tendency to read him along familiar lines (i.e., as arguing for internal understanding but external justification). This error has led to many misunderstandings of his views. See Dan Priel, Making Some Sense of Nonsense Jurisprudence (unpublished manuscript). Though Dworkin is in some respects the most prominent contemporary defender of this conception of authority, he developed it in such a way (combining it with elements of the custom-based view to be discussed below) that blurred the distinction between law and morality and gave a fairly small role to legal doctrine. This is why doctrinal lawyers committed to the practice-based view, while recognizing him occasionally as something of an ally, have remained ambivalent to his ideas. 
ultimately subject to a higher tribunal (of interpersonal morality, justice, welfare, and so on). This is why they will look at doctrinal lawyers who are uninterested in questions of "justification" with puzzlement and even some disdain. The blackletter lawyer's lack of interest in anything outside the cases strikes them as a sign of intellectual laziness (if not worse), for the idea that law can provide its own justification seems, from the externalist perspective on justification that is dominant in contemporary jurisprudence, almost impossible to understand. The mere fact that certain people behave in a certain way, thinking that their actions are authoritative, does not seem to be sufficient, even prima facie, for establishing the authority of the common law. But this attitude reflects the disconnect between contemporary legal philosophy and much common law thinking: Within the practice conception of authority, there is no higher tribunal for the justification of law. ${ }^{68}$ Some form of insularity, therefore, is a prerequisite of the job.

By contrast to the relative insularity of lawyers from nonlawyers, this approach tends to look favorably at cross-jurisdictional conversations among lawyers, or more precisely to some such conversations. Because the practice view gives considerable significance to path dependence and historical development, it will tend to be sympathetic to commonality among legal systems if they have a shared historical origin. Since authority on this view has its basis in history, the law of another jurisdiction can be significant (and compelling even if not binding) as long as the two legal systems have a shared history and can see themselves as belonging to the same "tradition." And here, obviously, the relevant tradition invoked is the "common law tradition." That is why proponents of this view insist on commonality among common law jurisdictions, while looking askance at suggestions that common law jurisdictions should convergence with legal systems that belong to a different "tradition." 69 I will return to this point below when I address the question of commonality among common law jurisdictions.

${ }^{68}$ For a clear statement of this view see T.E. Scrutton, The Work of the Commercial Courts, I CAmbridge L.J. 6, 8 (I92I) ("justice is not what we strive after in the Courts, paradoxical as it may seem....We are not trying to do justice, if you mean by justice some moral standard which is not the law of England."). Scrutton was at the time one of the most respected judges on the English Court of Appeal.

${ }^{69}$ See, e.g., Stevens, supra note 58, at 347; cf. Lord Hoffmann, Human Rights and the House of Lords, 62 MoD. L. REv. I59, I65 (I999). The question of convergence and divergence in the Commonwealth is further explored in Dan Priel, The Philosophies of the Common Law and their Implications: Common Law Divergences, Public Authority Liability, and the Future of a Common Law World, in Divergence And UniTy, supra note 43 , at 233 . 


\section{(c) Custom}

The common law is often described as custom from time immemorial. This is the historical sense of the common law just discussed under the heading of practice or artificial reason. In referring here to the common law as custom I have a different, although related, idea in mind: the common law as contemporaneous custom. ${ }^{70}$ On this view the common law is justified because, and to the extent that, it reflects prevailing norms of the community. If the law succeeds in reflecting prevailing custom, many problems with explaining its authority become less intractable. When law reflects prevailing custom, it reflects standards of behavior already accepted. This provides a solution to the common law's lack of adequate notice and publicity, as well as its alleged retroactivity. In this way this approach, with a dose of fiction, can explain the authority of law in terms of consent; not past consent (social contract), but as present, implied consent.

This way of understanding the common law is particularly appealing within a republican form of government. Central to republican thought is the idea of selfgovernment, i.e. that sovereignty ultimately resides with the people. One way of understanding this idea is that the solution to the problem of the justification of authority lies in creating a form of government in which the laws are not really imposed on their "subjects," but are rather created by the people themselves. When this is the case, these self-imposed laws cannot be seen as a limitation on the people's freedom, even if they remove some of the options available to them. ${ }^{71}$ This view sees the majoritarian devices we associate with "democracy" as a means or a technique, serving the end of republican self-government. To the extent that there are other (and in some contexts superior) techniques of attaining that end the fact that they are not adopted by a majoritarian representative body need not count against them. Judgemade law, even when created by unelected judges, is less problematic if the law created reflects accepted norms. Thus, if the practice-based approach to the common law can be seen as elitist, historicist, and closed, the custom-based approach is, in its ideal form, populist, presentist, and open. In this version of the common law its justification lies in its "social congruence," the idea "that disputes will be resolved under, and law will be based upon, the society's prevailing standards." 72

${ }^{70}$ On the ambiguity in the idea of custom on whether it is ancient or contemporary see Pocock, supra note 54 , at I3 I-32.

71 See Bernard Bailyn, The Ideological Origins of the American Revolution 76-79 (enlarged ed. I992); cf. Philip Pettit, Law and Liberty, in Legal Republicanism: National AND International Perspectives 39 (Samantha Besson \& José Luis Martí eds., 2009).

${ }^{72}$ Melvin Aron Eisenberg, The Nature of the Common LaW 44 ( I 988 ); see also id. at I 5 ("when moral norms are relevant to establishing, applying, or changing common law rules, the courts should employ social morality, by which I mean moral standards that claim to be rooted in aspirations for the community as a whole”). 
Karl Llewellyn provides an almost textbook statement of this view. In his account, both common law and statute must ultimately be immanent in the folkways of the people. "Savigny," he said, "may not have phrased a bull's-eye with his idea of the necessary conditioning of all law by the people's right-way-of-life, but right law which touches people must live in them. If law does not so live, it goes first technical; it goes then formal and remote. Remote law is not law to love, but law to dodge, or to use." ${ }^{73}$ Llewellyn brought home this democratic conception of law when he said that "the common law [is] at its high best" when it "ceases to be remote, when law comes home, [and] then a process works out among the citizenry of a democracy which is the exact analogue of the common law judicial sequence of self-correction, of judicial review of prior judicial decision-which is, indeed, its twin and needed brother." 74

Llewellyn sometimes described this conception of the common law in terms of "natural law which is real, not imaginary," but as he made clear, this conception of natural law was "not a creature of mere reason," but rather depends to a great extent on "the life conditions of the time and place." 75 As such, this natural law was "not eternal nor changeless nor everywhere the same, but is indwelling in the very circumstances of life." 76 This view gave particular place to the common law-and to the lawyer within the common law-as a conduit of values and attitudes of a particular people. It is a view of natural law in which "[g]uidance for a particular society must plant its feet in that society." 77 Thus, in stark contrast to the elitist

${ }^{73}$ K.N. Llewellyn, On the Good, the True, the Beautiful, in Law, 9 U. CHI. L. REv. 224, 262-63 (1942) [hereinafter Llewellyn, On the Good]. Contrast Llewellyn's view with Savigny's view, mentioned in note 78 , infra, that sees the process in which the law becomes technical as inevitable and even desirable. Elsewhere Llewellyn contrasted the view of law that sees legal principles as reflecting "rules-of-life wisdom" with the view sees them as "rules of order found inside the legal system itself and as such you don’t look outside.” Karl N. Llewellyn, How Appellate Courts Decide Cases (pt. I), I6 PA. B. Ass'N Q. 220, 226 ( I945). For the link between German romanticism and Llewellyn's views see James Whitman, Note, Commercial Law and the American Volk: A Note on Llewellyn's German Sources for the Uniform Commercial Code, 97 YALE L.J. I56 ( I 987 ).

74. Llewellyn, On the Good, supra note 73, at 264; see also Whitman, supra note 73, at I73, I 74.

75 Karl N. Llewellyn, The Common Law Tradition: Deciding Appeals i 22 (i 960).

${ }^{76} \mathrm{Id}$. For an earlier statement see Karl N. Llewellyn, One "Realist's" View of Natural Law for Judges, I 5 Notre DAme LAw. 3, 7 ( I939) (speaking of "a case-law system [in which] the verbal garb of rules is not fixed, and rephrasing is constantly and more closely approach a righter phrasing”).

${ }^{77} \mathrm{Id}$. at 6. Llewellyn argued, correctly in my view, that invocations of natural law in the work of historical figures of the common law had this conception of the common law in mind. See LLEWELLYN, supra note 75, at 422. For an exploration of this forgotten aspect of realist thinking see Dan Priel \& Charles Barzun, Legal Realism and Natural Law, in Law, Theory and History: New Essays ON a Neglected Dialogue (Maksymilian Del Mar \& Michael Lobban eds., forthcoming 20i6), available at http://ssrn.com/abstract=2589097. 
practice-based view, which seeks to insulate the common law from popular influence, this view insists that the common law must be in constant contact with it.

Still, it might seem odd to suggest that the common law reflects contemporary custom, because it seems so much more complex when compared to vague customary standards. ${ }^{78}$ But if understood as an account of the authority of the law (rather than of its content), then the concern can be, at least partly, assuaged. The practice view is not (or need not) assume that every decision of the common law reflects existing custom. Rather, the common law should aim to reflect prevailing social norms at a fairly high level of abstraction; specific decisions could still be seen to fit prevailing attitudes so long as they would be accepted by most people (if they put their minds to them). In practice, this implies that a custom-based version of the common law will acquire certain practice-based characteristics, but even then there remain differences between the two. As mentioned, practice is elitist and closed, seeing law as a lawyers' affair, while custom is populist and open. In more practical terms, for the custombased approach not to collapse to the practice-based approach, for it not to become a lawyer's affair that pays lip service to "the people," it must adopt certain institutional mechanisms that will enshrine its populism. To anticipate the argument below, this is exactly what we see in the American legal system, the legal system most closely committed to this conception of the common law's authority.

Because of the strong connection this view sees between the authority of the common law and the people of a particular political unit and the idea of selfgovernment, this view will tend not be particularly keen on commonality, regardless of whether that other jurisdiction is classified as a common law jurisdiction. ${ }^{79}$ It may allow for some commonality between communities that share certain values, but it will not insist on the significance of maintaining it. Even when we find such commonality, it will more likely be the product of different jurisdictions reaching similar outcomes relatively independently (because they happen to share some values), rather than as a result of a conscious effort to maintain commonality. Even when one finds such commonality, within this view there is not going to be much

${ }^{78}$ Savigny famously argued that the law is "the common consciousness of the people." FREDERICK Charles von Savigny, The Vocation of Our Age for Legislation AND Jurisprudence 28 (Abraham Hayward trans., I83 I). But he also said that law tends to develop in two stages, "first, as part of the aggregate existence of the community, which it does not cease to be; and, secondly, as a distinct branch of knowledge in the hands of the jurists." Id. Savigny thus saw a natural tendency to move from custom to practice.

${ }^{79}$ It is perhaps unsurprising that Llewellyn spoke of "English common law, and that very different something we know as American common law." K.N. Llewellyn, The First Struggle to Unhorse Sales, 52 HARV. L. REV. I, I (I939). At the same time, he rejected the Holmesian will-based view that each state has its own common law. See K.N. Llewellyn, On Our Case-Law of Contract: Offer and Acceptance (pt. I), 48 YALE L.J. I, 2, 5 ( I938). 
purchase to the view that commonality is valuable in itself and should be sought after as a goal.

\section{(d) Will}

The will-based conception is the view that sees the authority of all law, whether legislative or judge-made, as derived from an act of will of a person or body who is designated sovereign. In the English-speaking world this view received its most forceful articulation in the writings of Thomas Hobbes. Hobbes explicated this view in Leviathan and later, at greater length in his posthumously published Dialogue Between a Philosopher and a Student, of the Common Laws of England. Put together, these works can be seen as an unstinting attack on the three other suggested foundations for the common law and a defense of the view that it is the sovereign's will that provides the only basis for the authority of law, all law. As Hobbes put it, "our King is to us the Legislator both of Statute-Law and of Common-Law." 80

Hobbes definitely did not dismiss the idea of natural reason and its ability to discover certain rational truths. He agreed with Coke that "Reason is the Soul of the Law." ${ }^{81}$ He even called these truths natural laws and in his writings he went into quite some detail in explicating them. But as he made clear, these natural laws were not real law, simply rational precepts conducive to survival and peace. ${ }^{82}$ Hobbes was also emphatic that natural reason could not be the basis for legal authority, or as he put it, "it is not Wisdom, but Authority that makes a Law." 83 That is because there are endless disagreements about what reason requires, and so basing law's authority on moral correctness is bound to lead to chaos: "Would you have every Man to every other Man alledge for Law his own particular Reason? There is no amongst Men an Universal Reason agreed upon in any Nation, besides the Reason of him that hath the Soveraign Power." ${ }^{4}$ Though natural reason was available to all, it was, in fact, highly contested, and therefore it was a mistake to call it law: "it is by the Soveraigne Power that [natural law] is Law: Otherwise, it were a great errour, to call the Lawes of Nature unwritten Law; whereof wee see so many volumes published [by diverse authors], and in them so many contradictions of one another, and of themselves." ${ }^{85}$

80 Thomas Hobbes, A Dialogue Between a Philosopher and a Student, of the Common Laws of England, in Writings on Common LaW AND Hereditary Right I, 26 (Alan Cromartie \& Quentin Skinner eds. 2005) (I68I).

${ }^{81} \mathrm{Id}$. at 9.

82 See Thomas Hobbes, LeViathan i i i (Robert Tuck ed., i 996).

${ }^{83}$ Hobbes, supra note 80, at Io.

${ }^{84} I d$. at 26.

${ }^{85}$ HobBes, supra note 82, at I9I. (The words in brackets are not my emendation, they are Hobbes's words, which do not appear in all early printed editions of Leviathan.) Those wondering why reason, presumably available to all, could lead to such disagreements over the content of natural law, Hobbes provided a very modern response: people are not fully rational. It is true, he said, that "without partiality, 
And because the law of nature is law in virtue of the sovereign's will, what is law is the sovereign's interpretation of natural law, as determined by those to whom the sovereign delegates this power, namely judges. ${ }^{86}$

Unlike the sovereign's interpretations of natural law, judicial opinions do not create law: "Precedents are Judgments one contrary to another; I mean divers Men, in divers Ages, upon the same case give divers Judgments. Therefore I will ask your Opinion once more concerning any Judgments besides those of the King, as to their validity in Law." 87 The rejection of the practice-based account to the authority of the common law here is most uncompromising. The judge's opinion has authority only to the extent that it reflects the sovereign's view. "In all Courts of Justice, the Soveraign...is he that Judgeth: The subordinate Judge, ought to have regard to the reason, which moved his Soveraign to make such Law, that his Sentence may be according thereunto; which then is his Soveraigns Sentence; otherwise it is his own, and an unjust one." 88

Hobbes, however, did not leave it at that. He also stated that the idea of artificial reason available only to those who acquired learning in the law simply made no sense: "that the Reason which is the Life of the Law, should be not Natural, but Artificial I

and passion" anyone could discover the content of the laws of nature. But, alas, "there be very few, perhaps none, that in some cases are not blinded by self love, or some other passions," which is why the laws of nature are "now...the most obscure." Id. at I90-9I.

${ }^{86}$ See id. at I9I. The power given to judges to interpret natural law does not imply that the sovereign is bound by judges' interpretations. Neither the sovereign, nor other judges are bound by those interpretations if they think them mistaken. See id. at I92. Nor is the sovereign even bound to accept judges' interpretation in the particular case in which it was handed down, for the judges are the sovereign's delegates. Cf. id. at 396-97.

${ }^{87}$ Hobbes, supra note 80, at 55 (emphasis added). Relevant also is Hobbes's rejection of the doctrine of precedent, which is central to the practice-based view of authority. See HoBBES, supra note 82, at I9293.

${ }^{88} I d$. at $\mathrm{I} 87$. The explicit target of these words is Coke. For this reason I reject recent interpretations of Hobbes that try to portray him as someone who gives judges the power to challenge the sovereign on the basis of natural law. See, e.g., David Dyzenhaus, Hobbes on the Authority of Law, in HobBES AND THE LAW I86, I99 (David Dyzenhaus \& Thomas Poole eds., 20I2). This was exactly the view Hobbes attacked. He made it clear that "[T]he King is sole Legislator, but with this Restriction, that if he will not Consult with the Lords of Parliament and hear the Complaints, and Informations of the Commons, that are best acquainted with their own wants, he sinneth against God, though he cannot be Compell'd to any thing by his Subjects by Arms, and Force." Hobbes, supra note 80, at 26 (emphasis added). That the judges were not in some privileged position is clear from his general view that they were completely subordinate to the sovereign. See id. at 27 ("no Magistrate, or Commissioner for Publick Business, neither of Judicature, nor Execution in State, or Church, in Peace, or War, but he is made so by Authority from the King"). That does not yet make Hobbes a legal positivist in the way the term is used today. See Dan Priel, Toward Classical Legal Positivism, Io I VA. L. REV. 987, 999-I007 (20 I 5). 
cannot conceive." ${ }^{89}$ Hobbes more than hinted that Coke advanced this view in order to strengthen lawyers' power, ${ }^{90}$ and he dedicated considerable space to dismantling it. This is unsurprising, as this was perhaps the most prominent basis for the argument that the authority of the common law is distinct from the authority of the sovereign, a view that was at odds with the most basic tenets of Hobbes's political philosophy.

Hobbes was also critical of the idea of custom as the basis of authority. He did not discuss the particular version of custom-based authority considered here, present-day custom,,${ }^{91}$ but his view on ancient custom is nevertheless revealing. Custom on its own is completely lacking in normative force: "When long Use obtaineth the authority of a Law, it is not the Length of Time that maketh Authority, but the Will of the Soveraign signified by his silence, (for Silence is sometimes an argument of Consent;) and it is no longer Law, then the Soveraign shall be silent therein." ${ }^{92}$ He quotes the view advanced by some lawyers that "no Customes [can be] Law, but such as are reasonable, and that evill Customes are to be abolished," but immediately qualifies it with his own gloss: "But the Judgment of what is reasonable, and of what is to be abolished, belongeth to him that maketh the Law, which is the Soveraign Assembly, or Monarch." 93

Hobbes's view sees law as a tool of political authorities, and as such eradicates the distinction, so central to the other approaches, between law and politics. Law on this view is simply the means by which political authorities act. This approach can still maintain the importance of keeping adjudication free from political influence, which explains why Hobbes was consistent when he insisted on the importance of judicial

${ }^{89}$ Hobbes, supra note 80, at io. Bentham, whose theory of political authority bears important similarities to Hobbes's, offered a more positive argument for rejecting the authority of the past: "As between individual and individual living at the same time and in the same situation, he who is old possesses, as such, more experience than he who is young; - as between generation and generation, the reverse of this is true... [because] the old or preceding generation could not have had so much experience as the succeeding.... What, then, is the wisdom of the times called old? Is it the wisdom of gray hairs? No: it is the wisdom of the cradle." Jeremy Bentham, The Book of Fallacies, in 2 THE Works OF JeREMY BENTHAM 375, 398-99 (John Bowring ed., I 843).

${ }^{90}$ At one point Hobbes implies that Coke was motivated by his "desire[] to advance the authority of himself, and other Justices of the Common-Law." Hobbes, supra note 80, at 54. Like Bentham's wellknown attacks on lawyers, Hobbes also accused lawyers of increasing the amount of litigation for selfinterested reasons. See id. at 48-49.

91 I suggested earlier that the custom view of authority is tied to republican ideas of selfgovernment. Hobbes was deeply opposed to republicanism. See Quentin Skinner, LiberTy Before Liberalism io (i998); Philip Pettit, Made with Words: Hobbes on Language, Mind, And POLITICS I32-40 (2007).

${ }^{92}$ HobBes, supra note 82 , at I 84 .

${ }^{93}$ Hobbes, supra note 80, at I $84-85$. 
impartiality ${ }^{94}$ but this in no way affects the fundamental idea that all law, common law as well as statutory law, is inherently political. ${ }^{95}$

Because law is the means by which political authorities announce their "commands" for the sake of promoting the ends of that political community, there is no basis for seeing the law of any other nation as tied in some special connection to the law of any other. The common law is not some supranational legal system that exists as a brooding omnipresence in the sky. It is the law of a particular political unit, and it differs from other forms of law (statutes, executive directives) only by its means of promulgation. This Hobbesian view, which received its clear articulation in Holmes's dissent quoted above, is thus (at best) indifferent to the law of other nations, and often openly hostile to suggestions of common law commonality.

\section{(e) Beyond Ideal-Types}

Table I summarizes the main characteristics of the four ideal-types presented so far.

Table I: Four common law ideal-types

\begin{tabular}{|c|c|c|c|}
\hline Approach & Basis of authority & $\begin{array}{c}\text { Relationship between } \\
\text { law and politics }\end{array}$ & $\begin{array}{l}\text { Attitude to } \\
\text { commonality }\end{array}$ \\
\hline $\begin{array}{l}\text { Reason ("natural" } \\
\text { reason) }\end{array}$ & Reason & Strictly separate & $\begin{array}{l}\text { Commonality is } \\
\text { ideally universal }\end{array}$ \\
\hline $\begin{array}{l}\text { Practice } \\
\text { ("artificial" reason) }\end{array}$ & $\begin{array}{l}\text { The normative } \\
\text { force of tradition }\end{array}$ & $\begin{array}{l}\text { Largely separate, but } \\
\text { weak influence of } \\
\text { politics on law }\end{array}$ & $\begin{array}{l}\text { Limited to legal } \\
\text { systems that belong } \\
\text { to the same } \\
\text { "tradition" }\end{array}$ \\
\hline Custom & $\begin{array}{l}\text { Contemporary } \\
\text { acceptance }\end{array}$ & $\begin{array}{l}\text { No strict separation: } \\
\text { Influence of politics } \\
\text { on custom and } \\
\text { through that on law }\end{array}$ & $\begin{array}{l}\text { Only on the basis of } \\
\text { a (contingent) fact of } \\
\text { extra-legal similarity } \\
\text { in practices and } \\
\text { customs }\end{array}$ \\
\hline Will & Political sovereignty & Law is politics & Unsympathetic \\
\hline
\end{tabular}

${ }^{94}$ See HobBes, supra note 82, at I95-96.

${ }^{95}$ Hobbes, supra note 80, at I0. Hobbes says on several occasions that the common law is the law of reason. But his discussion makes clear that he uses the term "common law" in a different way from the lawyers'. For him the law of reason is common, because natural reason is available to all. What lawyers call "common law" is no different from any other law in the source of its authority. See id. at 27, I I 7 ("[Coke] makes the Common-Law, and the Law of Reason to be all one, as indeed they are, when by it is meant the Kings Reason.”) (emphasis added). 
In the real world philosophical ideas are rarely instantiated in pure form, which is why I described the four conceptions as ideal-types. It would be tedious to spell out in great detail all possible connections between the different ideal-types. I will, however, mention briefly a few such links which seem to me more relevant to understanding some of the arguments I develop below.

One often finds, sometimes within one work, the reason-based and practice-based approaches (i.e., natural and artificial reason) discussed together, ${ }^{96}$ perhaps because both are associated with some notion of reason. Thus, defenders of the idea that unjust enrichment occupies a fundamental area of English law constantly shift between the view that this is so because English courts have so declared (a practicebased argument), an argument used against those who challenge the view these authors find in the cases; and the view that unjust enrichment is a basic legal category regardless of what courts say, which is the view to which the same authors shift when they are unhappy with what they find in the cases. ${ }^{97}$ What this example also illustrates is that the common alliance between these two views is superficial, and often barely conceals fundamental differences between them. ${ }^{98}$

Another real-world alliance is between the "republican," custom-based idea and the will-based view, if the will is understood to be the will of the people. Since the will-based view is itself consistent with different views of who the sovereign is, it is by itself consistent with the republican idea of popular sovereignty. Here too, however, the two views can come into tension, if, for example, there is a growing perception that institutions understood to exist in order to make sure that the will of the people is reflected in the laws, become corrupted.

Alongside attempts to bring together two different conceptions of authority, in some instances we find hybrid accounts, which divide the domain of law. Such views explain the authority of the common law in one way and the authority of statute differently. Thus, it is common for those who think of the common law as grounded in practice to think of legislation as grounded in will. It is precisely this difference that

96 Compare STevens, supra note 58, at 330 (expressing a natural reason view) with id. at 2 I-22 (expressing a practice-based view).

${ }^{97}$ Compare Burrows, supra note 47, at 35 (responding to a critic of unjust enrichment law with the claim that "the tide of judicial opinion in England has explicitly turned against his rejection of unjust enrichment") with id. at 43 (arguing that "it is essential to the rationality and coherence demanded of the rule of law that unjust enrichment reasoning resumes its rightful place in Australian law"). This contradiction is the product of Burrow's attempt to fuse Birks's ideas (which owe much to the natural reason view) with his own methodology, which was much more committed to the practice-based approach.

${ }^{98}$ See note 48, supra, for an example. These differences are explored in greater detail in Dan Priel, Doctrinalism, Formalism, and Realism: An Essay on the Philosophy of Legal Doctrine (unpublished manuscript, in progress). 
explains why proponents of this view seek to keep common law and statute separate. ${ }^{99}$

\section{Why Did English-American Commonality Decline?}

We now have the theoretical apparatus to explain the decline of English-American commonality. In brief, my argument is that there are two dominant conceptions of the common law authority in the United States, the will and the custom views; by contrast, in England (and the rest of the common law world), the more dominant view in the last century has been the practice view. The first aim of this section is to substantiate my respective characterizations of the English and American understandings of the common law. I then hope to explain in more detail how different underlying rationales of common law authority play out on the question of commonality.

\section{(a) English Common Law as Artificial Reason}

The very same Dicey who extolled the similarities between English and American common law, also expressed the following view about the relationship between the common law and prevailing attitudes:

The Courts or the judges, when acting as legislators, are of course influenced by the beliefs and feelings of their time, and are guided to a considerable extent by the dominant current of public opinion....But whilst our tribunals, or the judges of whom they are composed, are swayed by the prevailing beliefs of a particular time, they are also guided by professional opinions and ways of thinking which are, to a certain extent, independent of and possibly opposed to the general tone of public opinion. The judges are the heads of the legal profession. They have acquired the intellectual and moral tone of English lawyers. They are men advanced in life. They are for the most part persons of a conservative disposition. They are in no way dependent for their emoluments, dignity, or reputation upon the favour of the electors, or even the Ministers who represent in the long run the wishes of the electorate. They are more likely to be biassed [sic] by professional habits and feeling than by the popular sentiment of the hour. ${ }^{100}$

This is an example of the practice view, which at least from the late nineteenth century has been the dominant conception of the common law in England. No doubt one could find proponents of other views (in fact, some of them have been mentioned earlier), but as far as I can tell Dicey's words reflect a dominant view.

Against the dominance of a predominantly Hobbesian (or, if you wish, Diceyan via John Austin) will-based foundation for the authority of legislation, the dominance of the practice-based approach to the common law has been an interesting political

${ }^{99}$ These hybrids are discussed in more detail in Priel, supra note 69, at 239-40, 245-47.

100 A.V. Dicey, Lectures on the Relation Between Law \& Public Opinion in England During the Nineteenth Century 363-64 (2d ed. I9I4) (emphasis added). 
success. On this view, the common law is seen as relatively separate from statute, as a distinct area of law that answers mostly to its own principles, which are largely unaffected by whatever changes take place in legislation. Though proponents of this view do not question the supremacy of legislation in all areas of law, they seek to keep legislation in "common law" areas to a bare minimum. ${ }^{101}$ While this is a speculation, it is possible that this view has proven attractive as a means for maintaining the judiciary as a counterbalance to legislative and executive branches that otherwise has almost unlimited power within the model of Parliamentary supremacy. By holding to the idea that the common law derives its authority from a different source, the courts could maintain a modicum of formal independence and on occasion the means for checking the other branches of government. ${ }^{102}$

Be that as it may, there are many less speculative aspects of the English approach to the common law that make sense when considered against its practice-based background. Take, for example, the importance attached by English lawyers to the ability to provide a firm explanation of an outcome from within existing legal materials, and the outright rejection of reasoning backwards from a desired result to its legal rationalization. It is not just that the idea that with some facility with legal materials one could reach any outcome whatsoever is rejected; what is interesting is the way it is rejected:

Any man who knows how to handle the professional apparatus of reference can find, with moderate industry, something like a show of authority for almost anything: and it is the delight of a certain class of advocates to snatch an advantage (though it is apt to be a fleeting one) by this method. But the law is not made by casual and hasty decisions in courts of first instance. Its guiding principles and the harmony of its controlling ideas must be sought in the considered judgments of the higher tribunals which command universal respect; and whatever is contrary to the general consent of leading authorities ought to be frankly discarded as erroneous. ${ }^{103}$

Pollock makes here the "realist" point that it is technically possible to find an "authority" for any desired outcome. This, however, does not undermine the authority of the common law or render it vacuous, because the common law's normative force, says Pollock, comes not from any individual case, but because the

${ }^{101}$ All this is presented as a natural phenomenon, merely reflecting the nature of how things are. I argue that this is not the case in Dan Priel, The Political Origins of English Private Law, 40 J.L. \& SoC'Y 48 I (20I3).

${ }^{102}$ Admittedly, though, either because of the inherent weakness of the common law (in its custombased conception), or because of a weak judiciary, much of the twentieth century was dominated by fairly little effective control of British government by the judiciary. See RoberT STEvens, The EngLish Judges: Their Role in the Changing Constitution 26-29 (2002); see also David Feldman, Public Law Values in the House of Lords, I06 LAW Q. REV. 246 ( I990).

${ }^{103}$ Pollock, supra note 34, at I I 4 . 
"considered judgments of the higher tribunals" and the "general consent of leading authorities." It is the community of lawyers that creates the sort of stability that enables law to become a scientific enterprise, i.e. making predictions about future legal decisions possible. ${ }^{104}$ Though calling the common law "the custom of the realm" had historical foundations, Pollock stated elsewhere, the custom in question had little to do with "English custom in any popular sense," but with "a specialised branch of learning worked out by rule." 105 And so, unlike the American conception of the common law, where a change in prevailing circumstances is itself deemed enough to change a legal rule, in England that change must be shown to be derived from the legal materials. And if this is (deemed) impossible, because, for example, the existing, unsatisfactory, rule is well-established then there is nothing that can be done about the matter, at least not until the legislature steps in and corrects the problem. ${ }^{106}$ As Lord Goff once admitted "the House of Lords will not reverse a decision of its own which is too young, or one which is too old, but only one which is, so to speak, middle-aged." ${ }^{107}$ While the reason for not upending a new decision is the familiar concern with maintaining legal stability and certainty, his reasons for not overturning old rules is highly revealing: "there is an underlying fear that a decision, if it stood for many years, may have become so embedded in the mosaic of the law that to reverse it would effect too great an upheaval of legal principle, or at least that the consequences of its reversal cannot be wholly foreseen." 108 The Burkean version of conservatism which I said underlay the practice-based conception of the common law is evident here.

104 See Frederick Pollock, Essays in Jurisprudence and Ethics 238 ( I882) ("Every special department of science occupies itself with predicting events of a particular kind.... The object of legal science... is likewise to predict events... [and the] events it seeks to predict are the decisions of courts of justice.").

${ }^{105}$ Frederick Pollock, A First BoOK OF Jurisprudence fOr Students of the Common LaW 242-43 ( I896); see also ALLEN, LAW, supra note 27, at I24.

106 See, e.g., Midland Silicones Ltd. v. Scruttons Ltd., [1962] A.C. 446, 468 (H.L. I96 I) (appeal taken from Eng.) (U.K.) ("The law is developed by the application of old principles to new circumstances. Therein lies its genius. Its reform by the abrogation of those principles is the task not of the courts of law but of Parliament"). For the implications of this view to the explanation of doctrinal changes in English and American law see Dan Priel, The Law and Politics of Unjust Enrichment, 68 U. TORONTO L.J. 533, 5576I (20I3).

${ }^{107}$ Lord Goff, Judge, Jurist and Legislature, 2 DENNING L.J. 79, 84 ( I 987 ).

${ }^{108} \mathrm{Id}$. at 85 . Contrast this with Holmes's famous dictum: "It is revolting to have no better reason for a rule of law than that so it was laid down in the time of Henry IV." Holmes, supra note $2 \mathrm{I}$, at 469. 


\section{(b) American Common Law as Will and Custom}

While the idea of self-government never gained dominance in England, it is implanted into American political DNA. ${ }^{109}$ Against this political background, adopting English common law as the legal foundation for the United States was doubly problematic. It was the law of a foreign nation, the very one against which Americans fought for independence, and its underlying conception of authority was one that clashed with the political sensibilities of the young republic. As a result, the American adoption of English common law looks puzzling at first; but the puzzle is to a large degree resolved when we see the way Americans have, from very early on, adapted English common law to republican ideology. The American Revolution was, to some extent, couched in terms of common law rights that have been denied, but the adoption of English common law was immediately accompanied by adaptation to American circumstances and politics. As Justice Story famously put it, "[t]he common law of England is not to be taken in all respects to be that of America. Our ancestors brought with them its general principles and claimed it as their birthright, but they brought with them and adopted only that portion which was applicable to their situation." 110

The view that adopts certain common law rules only to the extent that it fits the needs and conditions of the United States already reflects the beginning of a deeper reworking of the underlying philosophy of the common law. In adopting English common law, American writers emphasized a theme that was much less prominent in English writings: rather than lawyers' custom from time immemorial, the common law reflected the people's prevailing attitudes and norms at the time, and that it derived

${ }^{109}$ On the historical difference between the two countries on the matter see Gordon S. WoOd, ThE Creation of the American Republic, i 776-i 787, at 346-47, 362 ( I969); John V. Jezierski, Parliament or People: James Wilson and Blackstone on the Nature and Location of Sovereignty, 32 J. HIST. IDEAS 95 ( I97 I). On the absence of "the people" from British democracy see STUART WeIR \& DAVID BEETHAM, Political Power and Democratic Control in Britain 3i (ig99). This difference may have continuing relevance. See Jonathan Freedland, Why Do Brits Accept Surveillance, N.Y. Times, Nov. 9, 20I3, at A2 I, A2 I ("Britain has a fundamentally different conception of power than, say, the United States. In America, it is 'we the people' who are held to be sovereign.... The British system, by contrast, still carries the imprint of its origins in monarchy: Officially, it remains 'Her Majesty's Government,' not the people's. Power still emanates from the top and flows downward, with the public allowed a peek only when the state chooses. It means that Brits can be quite resigned toward the level of government power over, and intrusion into, their lives-because they don't really see government as their servant in the first place. Britons remain subjects, not citizens.”).

${ }^{110}$ Van Ness v. Pacard, 27 U.S. (2 Pet.) I37, I44 ( 1829 ). This view was widely shared among legal writers. See Simpson, supra note 38, at 67 ; Meyler, supra note 38, at 575-77. For a concrete example of such a change see Howard Schweber, The Creation of American Common Law, i850-i880: Technology, Politics and the Construction of Citizenship 66-67 (2004). 
its authority from that fact. ${ }^{111}$ In fact, it is perhaps more accurate to say that the willingness to change the content of common law rules to local needs was itself a reflection of the fact that from the start, English common law was superimposed on republican ideas of self-government, and it is this different theoretical foundation for the common law enabled the Americans to start changing the English common law fairly quickly. ${ }^{112}$

An interesting illustration of this development is seen in the American reception of Blackstone's Commentaries on the Lawes of England. It is well known that for much of the nineteenth century it was the most influential legal text in the United States. This may seem to run strongly against my claim that the authority of the common law was grounded in ideas of present-day custom, not least because Blackstone's Commentaries championed both Parliamentary (and not popular) sovereignty ${ }^{113}$ and the idea that the common law as artificial reason. ${ }^{114}$ Interestingly, however, from fairly early on Blackstone's text was supplemented with detailed commentary adapting it for American readers. Probably the most important of these glossators was St. George Tucker, who added extensive comments and explanatory essays to the American editions of Blackstone. ${ }^{115}$ One of the points of difference between the English and the American Blackstone was that "[s]overeignty, in the sense meant by Blackstone,

${ }^{111}$ See Craig Evan Klafter, The Americanization of Blackstone's Commentaries, in Essays ON ENGLISH LaW And the American Experience 42, 46-47, 53 (Elisabeth A. Cawthon \& David E. Narrett eds., I994).

${ }^{112}$ Llewellyn accepted that around the I830s and I840s there was "borrowing from England...in substance and in technique," but he insists that "the style of the then English law was borrowed not at all." Llewellyn, On the Good, supra note 73, at 237; see also Karl N. Llewellyn, The Bramble Bush: The Classic Lectures on the LaW and Law School I 73 (Steve Sheppard ed., 2008) (3d ed. i960) (American judges "have been conditioned by the tradition of the American bench, and of a particular American bench, which marks them off sharply from French or British or Canadian judges").

Schweber argues that as early as the I850s northern states began to forge "principles of tort, contract, and property...that...were entirely different from the inherited system of English law that they replaced." SCHWEBER, supra note III, at I. Some have claimed that the parting of ways began even earlier. See Robert Jorres Franklin, The Americanization of the English Common Law, I 776-I835, at 308 (unpublished Ph.D. diss., Univ. S. Cal., I972) ("even during the Colonial Period differences between the English Common Law and American legal concepts developed”).

113 See LobBAn, supra note 37, at 29 ("For Blackstone, sovereignty and the legislature were convertible terms, but they were not to be equated with the people as a whole"); LIEBERMAN, supra note 37 , at $49-52$.

${ }^{114}$ See id. at $40-45$.

115 See Robert M. Cover, Book Review, 70 Colum. L. Rev. I475, I475-76 (i970) (reviewing ST. George Tucker, Blackstone’s Commentaries with Notes of Reference to the Constitution and Laws of the Federal Government of the United States and the Commonwealth of VIRGINIA (Reprint I969) (I803)). 
properly resided for Tucker only in the "People." ${ }^{116}$ On the basis of this philosophical difference Tucker could add detailed discussions of the ways in which American needs and environment necessitated changes from the English common law. ${ }^{117}$ This difference remains to this day. Though the custom-based view is primarily a theory of the common law's authority, it is only within such an approach to the common law that one will find a commentator suggesting that in developing the common law courts should consult "popular sources, like newspapers and everyday conversation" 118 to determine the content of the common law.

Once the centrality of popular custom to American common law is understood, various structural features of the judicial process can be seen as institutional solutions designed to make sure the law reflects prevailing attitudes. For example, to most outsiders the prevalence of elected judiciary in many American states seems a baffling, even perverse, aspect of American law. ${ }^{119}$ But this practice looks much less strange when one recognizes that judges are involved in lawmaking. If law gets its authority from the fact that it reflects prevailing attitudes, and if it is acknowledged that judges make law, then popular control over the judiciary (in the form of elections) makes much sense: it introduces an institutional mechanism that may help guarantee that the law as created and applied by the courts reflects popular attitudes. Another device is the jury. Though jury trial is often named as one of the distinctive features of the common law world, American law remains far more committed to it than other common law jurisdictions. Part of the explanation for this fact is that in the United States juries are perceived as a popular lawmaking institution, a way of ensuring popular input into the process of lawmaking and a mechanism for checking the judiciary's development of the law. ${ }^{120}$

Holmes would have dismissed all this talk of the common law as empty piety. For him, law, like life more generally, was a struggle for power, ${ }^{121}$ and earlier I mentioned

\section{${ }^{116} I d$. at $\mathrm{I} 479$.}

117 See Klafter, supra note I I , at 57-59. Though Tucker's version is the best known, American revisions to Blackstone's ideas were made even earlier. See Dennis R. Nolan, Sir William Blackstone and the New Republic: A Study of Intellectual Impact, 5 I N.Y.U. L. REV. 73 I, 74 I-42 ( I976).

${ }^{118}$ EisenberG, supra note 72, at I 7. Contrast this with Dicey's view quoted in text accompanying note ioo, supra.

119 See, e.g., Adam Liptak, Rendering Justice, with One Eye on Re-Election, N.Y. Times, May 25, 2008, at AI, AI (judicial elections are "virtually unknown" outside the United States).

120 See, e.g., Steven Hetcher, The Jury's Out: Social Norms' Misunderstood Role in Negligence Law, 9I GeO. L.J. 633 (2003); Jenny E. Carroll, Nullification as Law, I 02 GEO. L.J. 579 (20 I4).

121 See Albert W. Alschuler, Law Without Values: The Life, Work, and Legacy of Justice Holmes i6-29 (2000). For an example of Holmes's view on the place of force in life see Letter from O.W. Holmes to Frederick Pollock, Feb. I., I920, in 2 Holmes-Pollock LetTers: The Correspondence of Mr Justice Holmes and Sir Frederick Pollock i874-i932, at 36, 36 (Mark DeWolfe Howe ed., I942) ("I do think that man at present is a predatory animal. I think that the 
his view, adopted by a United States Supreme Court majority in Erie, that presented an unromantic will-based approach to all the law. This too may seem to conflict with my characterization of American common law as custom-based. But the two approaches can be aligned together by treating American sovereignty as residing in the people. ${ }^{122}$ Though it does not take too much imagination (only a rudimentary knowledge of American politics) to see how these two perspectives can come into conflict, on the question of commonality they arrive at fairly similar conclusions. The will-based view rejects commonality because all law is the product of sovereign power; the customary view rejects commonality because all law reflects local attitudes. The latter view could countenance commonality as long as there was reason to think that the customs of England and of the United States were the same. But as time went by there was less and less reason to think that. Perhaps more importantly, even in those cases in which commonality would be found, it would be a coincidence, not something to care much about and definitely not something to strive for. There is, on this view, something suspicious about seeking affirmation for one community's local values and customs in the laws or attitudes of another. In the American context, the view that such efforts really are nothing more than an attempt of an unelected elite to force its values on "the people" is not a fringe claim: one finds it in the United States Reports. ${ }^{123}$

\section{(c) Some Anglo-American Differences Explained}

Many of the differences between English and American common law become easier to understand when the theoretical difference in understanding their respective basis of authority is taken into account. I already mentioned the differences with regard to elected judiciary and jury trial; here, I will mention a few others. ${ }^{124}$ As they all rely on the preceding discussion, I can discuss them all relatively briefly.

sacredness of human life is a purely municipal ideal of no validity outside the jurisdiction. I believe that force, mitigated so far as may be by good manners, is the ultimo ratio, and between two groups that want to make inconsistent kinds of world I see no remedy except force. I may add what I no doubt have said often enough, that it seems to me that every society rests on the death of men.").

${ }^{122}$ Cardozo attempted to fuse will and custom under the banner of "pragmatism." He accepted that law is "an historical growth" and "an expression of customary morality" but also occasionally involves "a free exercise of will" and "a conscious and purposed growth" which can happen only when "the mind of the judge is directed to the attainment of the moral end and its embodiment in legal forms." BENJAMIN N. Cardozo, The Nature of the Judicial Process io2-05 ( I 92 I ).

123 See Roper v. Simmons, 543 U.S. 55 I, 628 (2005) (Scalia J., dissenting).

${ }^{124}$ They may be a few others still that I will not consider in this essay. See Priel, supra note Io6, at 567-68 (explaining debates between common law scholars on the nature of the law of restitution); Priel, supra note 69, at 249-52 (arguing that disagreement on the tort liability of public authorities are related to different views on the authority of the common law) 
The common law and democracy. Perhaps the most striking difference between the English and the American approaches is the relationship to democracy. American common law is explained in terms of democracy, as a manifestation of democratic principles; English common law is explained (and at times even justified) by its defenders as a justified exception to democracy. ${ }^{125}$

In much American common law thinking law is seen as an important source for the infusion of popularly-accepted norms into the law. These views about the common law are part of a network of other ideas that see law as a popular product. For example, there are many attempts to show the extent to which American constitutional law (which in many respects resembles common law much more than statutory law) moves with and is shaped by public opinion. On this view, there is a bidirectional influence, or a dialogue, between courts and the people. First, though courts play a significant role in the shaping of public policy, they are attentive to popular opinion and are rarely out of tune with it. From the other direction, it has been argued that courts play an active and useful role in instigating and fostering the kind of debate that is seen as central to the functioning of a democracy founded on ideas of self-government. This idea of a deliberative, participatory, democracy is much more deeply ingrained in the American version of democracy. ${ }^{126}$ So understood, it is easier to explain judicial review of legislation not as a departure from democratic principles, but as an affirmation of popular democracy and an important feature of a republican form of government. Ronald Dworkin, for example, stated that

[w] hen a constitutional issue has been decided by the Supreme Court, and is important enough so that it can be expected to be elaborated, expanded, contracted, or even reversed, by future decisions, a sustained national debate begins, in newspapers and other media, in law schools and classrooms, in public meetings and around dinner tables. That debate better

125 Compare Karl N. Llewellyn, American Common Law Tradition, and American Democracy, I J. LEGAL \& POL. SOC. I4, 37 ( I942) (within the American "grand style" common law the "daily criterion of sound work is sought outside the legal system proper....[T] reason is living must be determined from current life...") with Birks, supra note 29, at 98 ("The legitimacy of expert law-making in a sophisticated democracy depends on the truth of the assertion that the interpreters are and must be both the masters and the servants of a complex system of reasoning. Why are they not elected? The answer must be that they are doing something different from the legislator and something that cannot be done by just any commuter on the Clapham bus.”).

126 See Gabriel A. Almond \& Sidney Verba, The Givic Culture: Political Attitudes and Democracy in Five Nations 455-56 (I963) ("Despite the spread of political competence and participant orientations, the British have maintained a strong deference to the independent authority of government....If in the [United States] there tends to be too much weight placed on the participant role, in Britain the deferential subject role is more strongly developed and widespread"); see also note Io9, supra. 
matches [the] conception of republican government, in its emphasis on matters of principle, than almost anything the legislative process on its own is likely to produce. ${ }^{127}$

This idea is far less dominant in Britain, whose dominant conception of democracy has been described as "democratic élitism," which "restricts public participation to a periodic take-it-or-leave-it choice between competing political élites, [but otherwise] freeing the elected group to do as much as it will between elections." 128 Against this conception, it is unsurprising that a prominent British judge dismissed the idea that appellate courts should participate or encourage this kind of public deliberation. "Professor Dworkin," he wrote, "may enjoy the high level of debate about Roe $v$ Wade over the dinner table and with his taxi driver but I can do without it. And the same goes for many other issues...which for better or for worse have in this country been the subject of comprehensive legislation." ${ }^{129}$ It is the dominance of this perspective which explains why judicial review is still thought to be in tension with Parliamentary supremacy, and to the extent that it is justified, is justified in terms of the elitist conception of democracy, that is, as itself the product of Parliamentary legislative choice. ${ }^{130}$

What is interesting is that in the American context, much of the opposition to Dworkin's ideas comes from the exact opposite direction, namely from critics who think that something like his conception of constitutional law (together with its justifications of judicial review) is insufficiently participatory. True self-government, these critics say, means "popular constitutionalism," a view that seeks to give a more prominent role to "the people themselves" in the shaping of constitutional doctrine, a view that implies "taking the constitution away from the court." 131

Codifying the common law. Much of American "common law" (if by this we mean areas like contract and tort) is legislated. In a legal system in which common law and legislation are simply seen as law, this is not thought of as remarkable. Indeed, the opposite may well be the case. The idea that these areas of law have the status of law

${ }^{127}$ Ronald Dworkin, Freedom's Law: The Moral Reading of the American Constitution 345 (I996); Barry Friedman, Dialogue and Judicial Review, 9I Mich. L. Rev. 577, 654, passim (I993). Numerous other examples of similar sentiments are mentioned (although not endorsed) in GERALD N. Rosenberg, The Hollow Hope: Can Courts Bring about Social Change? 25-26 (2d ed. 2008).

${ }^{128}$ Feldman, supra note I02, at 247. Feldman analysis analyzed the House of Lords' public law decisions and found in them "no real enthusiasm for a more participatory model of democracy." Id. at 255 .

${ }^{129}$ Lord Hoffmann, Bentham and Human Rights, 54 Current Legal Probs. 6i, 73 (200 I).

130 See, e.g., JefFrey Goldsworthy, Parliamentary Sovereignty: Contemporary Debates 299 (20I0).

131 The quoted words are references to the titles of two books advancing such ideas. See LARRY D. Kramer, The People Themselves: Popular Constitutionalism and Judicial Review (2004); Mark Tushnet, Taking the Constitution Away from the Courts ( i 999 ). 
despite not being confirmed by a popularly-elected legislature may seem problematic, and the unavailability of such laws to people an affront to the rule of law. The prevalent hybrid approach (will for legislation, practice for the common law) in England explains why common law and legislation are still treated like "oil and water." ${ }^{132}$ Here, the codification of the common law is seen as "dangerous." 133

American states, much more than the rest of the common law world, have codified their common law areas of law. In the rest of the common law world there is, to this day, resistance to codification (or, for that matter, even to more minor legislative "interventions" in the common law). A likely (although rarely acknowledged) reason for this resistance is that a codified common law will be much more naturally seen as an act of will, laid down by the democratically-elected parliament, and binding only in the country in which that legislative body enjoys political authority, and not as a separate legal order, whose authority comes from some other source. ${ }^{134}$

The relationship of common law and statute. Closely related to the last point is the question of the perceived relationship between the common law and statute. Unlike English law, where for a long time the prevailing view has been that the common law and statute law are two fairly independent bodies of law that are largely concerned with different areas of law, operate on different principles, and should be generally kept apart from each other, American law has been much quicker to embrace the idea that judge-made and legislature-made law are simply two different ways of lawmaking, and that they must be considered in tandem in dealing with legal problems. $^{135}$

${ }^{132}$ Beatson, supra note I35, at 300 (Beatson's description for the prevailing attitude in England).

${ }^{133}$ Burrows, supra note 58, at I36. Apparently, Burrows thinks that judges' using the terminology of quasi-contract is a violation of the rule of law, BURROwS, supra note 97, at 28, but making the law more accessible to non-lawyers with a publicly promulgated statute is not. Quite the contrary: completely in line with the practice-based view, Burrows mentions the need to maintain the law as an elitist as a reason against codification. Codifying the common law, he says, "would tend to destroy" the "new working relationship" between courts and legal academics. BURROWs, supra note 58 , at I 36.

${ }^{134}$ Birks comes close to admitting this in Birks, More Logic, supra note 48, at I 89 ("The common law will be killed by an English Civil Code. Neither its character nor its world-wide communion would survive.").

135 Compare Jack Beatson, Has the Common Law a Future?, 56 Cambridge L.J. 29I, 300 (I997) (describing the prevailing common law view as "statutes and common law flow next to but separately from each other in their separate streams") and Robert Stevens, The Divergence of the Australian and English Law of Torts, in TorTs in Commercial LaW 37, 40 (Simone Degerling et al. eds., 20i I) ("[1]egislatures are a law unto themselves") with Roscoe Pound, Common Law and Legislation, 2 I HARV. L. REv. 383 ( I 908), Harlan F. Stone, The Common Law in the United States, 50 HaRv. L. REV. 4, I 2-I5 (I936), and James McCauley Landis, Statutes and the Sources of Law, 2 HARV. J. ON LEGIS. 7 ( 965 ) (reprinting an article from I934) (all three offering a more unified view of common law and statute law). 
The force of precedent when circumstances change. In the United States it is common to say that precedents lose their normative force when the social circumstances that existed when they were formed disappear. ${ }^{136}$ English lawyers and judges are much more reluctant to change deeply entrenched, very old, precedents, ${ }^{137}$ even though the age of the precedent may be a strong indication that it was created at a time when social circumstances were very different from what they currently are.

Legal scholarship. I mentioned briefly earlier the difference in style and content of leading American and English legal journals and the nature of legal scholarship. Especially in the context of common law subjects like contract or tort law, English scholarship is far more doctrinal. ${ }^{138}$ To American legal scholars much of this scholarship looks about a century out of date, but what this attitude cannot explain is why such scholarship remains popular and why the allure of interdisciplinary scholarship so resistible. There are numerous explanations for this phenomenon; these include the diversity among the U.S. fifty jurisdictions as opposed to the relative unity of these subjects in other common law jurisdictions where their highest appellate courts provide fairly uniform solutions for the entire country; the organization of the bar; and the different structure and culture of legal academia in the United States as opposed to the rest of English-speaking world. ${ }^{139}$ While I do not wish to dismiss these explanations, in my view these differences themselves can, at least in part, be explained not as alternatives to the account offered here, but as the product of the same differences in political ideology which form the core of my argument. The practice-based approach encourages thinking of the common law as an autonomous discipline, where answers to new problems must be sought from the law's own materials. From this perspective nondoctrinal scholarship is not simply unnecessary; it is in some sense positively dangerous. By contrast, both the custombased and the will-based approaches will be far more open to nonlegal contributions.

I mentioned earlier that Rabban portrayed English and American legal history as proceedings these days on "independent tracks," despite considerable convergence in

${ }^{136}$ Guido Calabresi, A Common LaW for the Age of Statutes 2 I-23 ( I 982); Llewellyn, supra note I I 2, at I 74 .

${ }^{137}$ See text accompanying notes I06-I08, supra.

138 Already twenty years ago Richard Posner reported that in an American law school doctrinal scholars "have a sense of exile." Richard A. Posner, Overcoming LaW 88 (i995). Around the same time, Zimmermann noted that in England, such scholarship remains respected and even prominent. See Reinhard Zimmermann, Savigny's Legacy: Legal History, Comparative Law, and the Emergence of a European Legal Science, I I 2 Law Q. REv. 576, 584 ( 1996). It seems to remain so today. See Susan Bartie, The Lingering Core of Legal Scholarship, 30 LEGAL STUD. 345, 357-58 (20 I 0).

139 See Jane Stapleton, Benefits of Comparative Tort Reasoning: Lost in Translation, in TOM BIngHaM and the Transformation of the Law: A Liber Amicorum 773, 793-95 (Mads Andenas \& Duncan Fairgrieve eds., 2009). 
methods in the nineteenth century. Rabban made this claim as part of a broader argument that has sought to challenge the perception of nineteenth century American law and legal scholarship as formalist. Instead, he says, it is better described as "historicist." The argument presented here helps make sense of these claims. If my argument is correct, the realists' overthrow of "formalism" which is nowadays part of American legal mythology, should be understood as a rejection of two distinct views often conflated under the banner of "formalism," the natural reason view and the artificial reason view. Once we see that the label "formalism" is used to describe these two often-confused views, we can refine the realists' arguments. As I see it the realists' target was not the view that law must be derived deductively from abstract legal principles, i.e. not as a rejection of the natural reason approach; the realists challenged a historicist-elitist view and sought to replace it with a more presentistpopulist view. Even if not purely deductive, the view the realists have sought to displace still saw law as an elitist, apolitical, and arcane science. Properly understood, then, Rabban's account is not a challenge to the familiar story about the realists' critique of Langdellian formalism, it is an affirmation of it.

Furthermore, we can now also make sense of the divergence Rabban described among the practices of contemporary legal historians. It is notable that many of the American legal historians Rabban discussed had strong links with Harvard Law School, where the practice-based conception of the authority of the common law was dominant at the time. This view lends itself to the kind of "internal," doctrinal, legal history, one that examines changes in the law by more-or-less exclusive focus on "traditional" legal materials (cases, treatises, textbooks etc.) in relative isolation of discussion of the relationship between law and society. That is why there could be a meaningful transatlantic conversation between them.

Against the background of a continuing dominance of law as artificial reason in England, it is unsurprising that a "closed" kind of legal history is still dominant in England. ${ }^{140}$ With the custom-based approach (re-)asserting itself in the United States,

${ }^{140}$ Of course, there are many British legal historians who write about legal history in relation to changes in broader society, but the doctrine-focused approach to legal history, "internal legal history" as it is sometimes called, is still a very dominant strand in English legal history. See David Ibbetson, What Is Legal History a History of?, 6 CURREnT Legal Issues 33, 34 (2004). A recent article provides a more specific illustration. The article complained about the narrowness of historians' explanation of legal change. It is notable, however, that the complaint was not that legal scholars should pay more attention to the way societal changes affect legal doctrine. Rather, it was that legal scholars should pay more attention to the complexity of the internal legal mechanisms that influence the law. For example, "judgments should not be seen as free-standing artefacts, independent of the processes of production that have given rise to them. Rather,...the law report of a case is an imperfect and incomplete record of an event....Judgments respond to counsel's arguments, but increasingly arguments are not reported at all." Paul Mitchell, Patterns of Legal Change, 65 Current Legal Probs. I77, i82-83 (2012). Indeed, 
this approach to legal history fell out of favor. Instead of tracing law through changing doctrine, law came to be seen as a reflection of prevailing attitudes of the day, and correspondingly American legal history became much more interested in studying changes in legal doctrine not in relation to path-dependent but isolated legal doctrine, but much more in relation to the contemporaneous social attitudes. This explains why the dominant approaches to legal history writing in the two countries are now rather different. The very different ways in which English and American legal historians see their subject-matter thus reflects different understandings of the authority of the common law.

Federalism and the common law. As just mentioned, differences in legal scholarship have been explained in terms of the different form of federalism in the United States on the one hand, and other federal common law countries such as Australia and Canada. Arguably, however, this difference is itself an aspect of the ideological difference offered in this essay. (As my focus in this essay is on the differences between the United States and England, I will not explore this point in any detail.) The American version of federalism countenances, and to some extent even celebrates, different common laws for the different states. It is notable, that Australia and Canada are far more committed to a national common law, ${ }^{141}$ something that may possibly be explained by the fact that the practice-based view has been far more dominant in these countries.

\section{(d) Explaining the Decline in Anglo-American Commonality: The New Puzsle}

Following what I have said in this section the question of the divergence between English and American common law may now appear in a different light. The right question may seem to be not why commonality declined but why it ever existed. For if I am right, the American conception of the common law should have been unsympathetic to outside contributions from the start. The custom-based view could rely on customs of other countries when those could be thought to be similar to American ones, but these days, this is a problematic assumption. From the other side, there is a different kind of problem with maintaining commonality, perhaps less acute, but still significant. The practice-based approach is based on a fairly strong separation between law and politics. It is, in fact, this separation that allows for

when discussing legislative changes that happened in response to external pressures, Mitchell complains that such changes "strike[] a dissonant note when placed next to more general, common law principles." Id. at I9I. In short, such changes are problematic because they undermine the image of law that the practice-based scholar seeks to cultivate.

${ }^{141}$ See Leslie Zines, The Common Law in Australia: Its Nature and Constitutional Significance, 32 FED. L. REv. 337, 344-5 I (2004) (the dominant view in Australia accepts a "common law of Australia"); I PETER W. Hogg, Constitutional Law of Canada $\$ 8.5(\mathrm{a})$, at 8-i2 (5th ed. 2007) ("the Supreme Court of Canada does not tolerate divergences in the common law from province to province"). 
borrowing from other the common law of other countries. But as American common law itself is conceived of in political terms, relying on its solutions may seem more problematic for its potential to "taint" the seemingly apolitical common law.

Why then did Dicey speak of Anglo-American commonality and of the similarity between the two countries' laws in such enthusiastic terms? Did he not notice the differences? ${ }^{142}$ My answer is twofold. First, to understand Dicey's remarks we need to understand the wider political context in which they were made. Second, American common law at the time, especially in the form with which Dicey was most familiar, embraced ideas that brought it closer to the practice-based conception. I will consider these two points in turn.

The period around the turn of the twentieth century, is known as the period of the "great rapprochement" between the United States and Britain. This AngloAmerican alliance was conceived as a counterbalance to the rising forces of Germany and France. ${ }^{143}$ Coincidentally or not, this diplomatic rapprochement was accompanied by an ideological one. Some academic liberals (in the nineteenth-century sense of the term) came to see the United States as a living beacon of a society committed to English (or Anglo-Saxon) freedom grounded in the common law. ${ }^{144}$ Dicey, along with several other Oxford professors, was part of that group, and was in fact not alone in suggesting some kind of political unity, or even joint citizenship, between the two countries. Around the same time James Bryce, a former Regius Professor of Civil Law at Oxford and future British ambassador to the United States, made a similar suggestion, ${ }^{145}$ and similar ideas were expressed with relative frequency by others at

${ }^{142}$ One could even say that he dismissed them. Almost two decades before the essay which I quoted in the beginning, Dicey wrote: "That [American] law is founded on that of England is common knowledge. A point not so often noticed is that the growth of republican society has to a far slighter extent than might have been anticipated changed either the substance or the form of the legal rules brought from the old country.” A.V. Dicey, An English View of American Conservatism, 30 NATION 228, 229 ( 1880 ). I will argue that Dicey was wrong here; or if not wrong when he wrote it, that within a few decades republican ideas have changed the American conception of the common law.

143 See generally Bradford Perkins, The Great Rapprochement: England and the United States i895-i9i4 (i968); Charles S. Campbell, From Revolution to Rapprochement: The UNITED STATES AND GREAT BRITAIN, I 783-I900, at I9I-204 ( I974).

${ }^{144}$ For some relevant context see H.A. Tulloch, Changing British Attitudes towards the United States in the I $880 s, 20$ HIST. J. 825 ( I977).

145 See James Bryce, The Essential Unity of Britain and America, ATLANTIC MonTHLY, July i 898, at 22, 29. On Bryce's views on the United States see Tulloch, supra note I44, at 826-36. Another prominent Oxford professor advancing such views was Edward Freeman, Regius Professor of Modern History. On

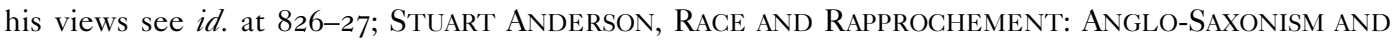
THE ANGLO-AMERICAN RELATIONS, I 895-I904, at 39-40 ( I98 I). 
the time, and not just on the Eastern side of the Atlantic. ${ }^{146}$ Nevertheless, it appears to have been an elite affair, not something that excited the general public. A year after the publication of his original plea for "isopolity," Dicey reported that his "proposal fell flat," that "[i]t excited no attention in England," and that the tone of the "few friendly letters from the United States... was not encouraging." ${ }^{147}$ In part, therefore, Dicey's claims about the similarities between the two legal systems should be read in relation to his politics, rather than as a dispassionate presentation of reality.

In fairness to Dicey, it seems like his claims were not a figment of his imagination. Dicey's main contacts and sources of information about American law were from his correspondences and meetings with members of the faculty of Harvard Law School. And it seems that when he spoke of the similarity between the law of the United States and England, he was in some sense talking more about the similarity between the law professors at Harvard and Oxford, a fairly short-lived connection forged between the two law schools in the late nineteenth century. ${ }^{148}$

In both institutions a central question at the time was how to justify the study of law in a research university. To justify the academic instruction to a profession traditionally taught by way of apprenticeship, it had to be shown that the study of law could be "scientific." Germany, where the modern research university was invented, provided a model. ${ }^{149}$ The problem was that German legal science at the time was dominated by the natural reason model, which was alien to common lawyers' thinking and to the dominant role they gave to cases. Instead of the rationalistic inquiry, more geometrico demonstrata, that was the staple of the German legal science, the common law version of legal science favored an inductive study that started with the cases and tried to identify underlying doctrines and principles implicit in them. This is the

${ }^{146}$ For American support for this idea see John R. Dos Passos, The Anglo-SaXon Century AND The Unification of the English-Speaking People (i903). In arguing for the alliance between the two countries Dos Passos also cited the similarity in law between England and America. See id. at I34-35. The book ends with a survey of numerous suggestions made at the time for some alliance (not necessarily amounting to a joint citizenship) between the two countries. See id. at 2 I I-35.

147 A.V. Dicey, England and America, ATlantic Monthly, Oct. i898, at 44I, 44I. Dicey remained undeterred and kept "the dream, or the hope" that the growing unity between the countries would eventually lead to common citizenship. See id. at 445 .

148 This connection is the subject of CosGrove, supra note 28, passim; see also Robert W. Gordon, Book Review, 94 HaRV. L. REV. 903, 9I I (I98I).

${ }^{149}$ The invocation of Germany as a model is explicit in, for example, James Barr Ames, The Vocation of the Law Professor, 48 AM. L. REg. I29, I4 I ( I900). On the influence of the German model on American law schools see generally Mathias Reimann, A Career in Itself[:] The German Professiorate [sic] as a Model for American Legal Academica [sic], in The Reception of Continental IDEAS In The Common Law WORLD I820-I920, at I65 (Mathias Reimann ed., I993). The influence on England (sometimes by way of rejection) is discussed in Enid Campbell, German Influences in English Legal Education Jurisprudence in the Igth Century, 4 U.W. AusTL. ANN. L. REV. 357 ( I959). 
version of legal science championed by Langdell at Harvard at the time, ${ }^{150}$ and it is the model defended by Dicey in his Inaugural Lecture to the Vinerian Chair at Oxford: "By adequate study and careful thought whole departments of law can thus be reduced to order and exhibited under the form of a few principles which sum up the effect of a hundred cases." ${ }^{151}$ The scientific analogy was less deductive geometry, more inductive botanical classification. ${ }^{152}$

Legal science at both Oxford and Harvard thus meant something close to the practice-based view of the common law. The law's principles were not simply a reflection of popular attitudes: for those there was no need for a careful study of the cases in the library, the lawyer's laboratory. ${ }^{153}$ The practice-based approach could be considered scientific by advancing a conception of law as a form of expertise properly reserved for trained elites. Their training consisted in learning to discover the principles of the common law. ${ }^{154}$ It was is the validity of these principles, embedded in the long history of the common law, that guaranteed its separation from the sway of contemporary politics; and it was this separation of law from politics that guaranteed the law's scientific objectivity.

In the United States, legal practice became more professional and "formal" in the course of the nineteenth century; ${ }^{155}$ and Harvard Law School provided a model for the rest of American legal education on the right approach to educating this upwardly mobile profession. It is this image that many of those who passed through law school at the time (either at Harvard or in other leading law schools) that help foster the Anglo-American common law alliance described in the beginning of this essay.

${ }^{150}$ Contrary to familiar perception, Langdell did not support the view of law as natural reason, of general principles from which particular decisions are derived. See C.C. LANGDELl, A SELECTION OF Cases ON THE LAW OF CONTRACT, at vi (I87I) ("Law, considered as a science, consists of certain principles or doctrines....Each of these doctrines has arrived at its present state by slow degrees; in other words, it is growth, extending in many cases through centuries."). For another exponent of these ideas at Harvard see, for example, Beale, supra note I 54, at 282-83; cf. Ames, supra note I 49, at I39.

151 A.V. Dicey, Can English Law Be Taught at the Universities? 20 ( I 883).

152 See Marcia Speziale, Langdell's Concept of Law as Science: The Beginning of Anti-Formalism in American Legal Theory, 5 VT. L. REV. I, 27 (I980).

${ }^{153}$ According to C.C. Langdell, Teaching Law as a Science, 2 I AM. L. REV. I23, I 24 ( I887).

${ }^{154}$ See Joseph H. Beale, Jr., The Development of Jurisprudence During the Past Century, I 8 HaRv. L. REv. 27 I, 282, 283 ( I 905) (Bentham's efforts to "build a new system [of law]...merely by deductive reasoning" were not scientific, but "a marvel of egotism and self-conceit....We are living in an age of scientific scholarship...[in which] we learn from scientific observation and from historical discovery.”).

155 See Gordon S. Wood, The Radicalism of the American Revolution 323-24 (i99i). Karl Llewellyn suggested that from around I 885 to I9I o American courts were dominated by what he called the "formal style." See Llewellyn, supra note I25, at 33. If one accepts these claims, it would suggest that Dicey's claims were correct for the time he made them. If that is indeed the case, the dominance of Harvard Law School provides a partial explanation for this phenomenon. 
This conception of the common law functioned reasonably well for a while, with the practice-based conception of the common law helping to work out a fairly internally coherent legal doctrine. But this conception came under increasing pressure on both sides of the Atlantic with the growth of the administrative state. And because of the two countries' different political traditions, they reacted very differently to it. American common lawyers worked to bring together common law and statute, showing how both can be seen as a product of a self-governing people; in England, the response was by insisting on a clear separation between the two, maintaining the common law as a kind of lawyer's law that should be kept free from "political" interventions, while statute was the product of the sovereign. ${ }^{156}$ An emphasis on the democratic nature of the contemporary custom conception of the common law was part and parcel of that response. This is the key to understanding the realist attack on Langdell and Harvard Law School, and perhaps even more than that, its success. ${ }^{157}$ For Karl Llewellyn in particular, this opposition was not at all a challenge to the study of law through cases, nor was it a critique of the common law. ${ }^{158}$ It was a challenge to the perception that the practice-based way of teaching the cases reflected a misguided philosophy of the common law, one that was both alien to the American common law tradition and was normatively unappealing.

\section{Conclusion}

The body of materials we call "common law" has been in existence for so long and in so many places, and benefited from the contributions of so many people that it would have been incredible if we found it perfectly coherent. This fact is usually invoked to explain the messiness of common law doctrine, but in this essay I suggested that it is also relevant for understanding the common law's theoretical foundations. What I have attempted to show is that this theoretical messiness helps us understand various seemingly disparate questions. I have further sought to show that these differences can ultimately be traced to seemingly unrelated questions about the relationship between law and politics, about the basis of political authority, and even the meaning and role of democracy.

\footnotetext{
${ }^{156}$ See Priel, supra note Io I, at 490-500.

${ }^{157} \mathrm{It}$ is the failure to see this that undermines much of the argument in TAMANAHA, supra note 32.

${ }^{158}$ I thus partly disagree here with Frederick Schauer, Is the Common Law Law?, 77 CAL. L. REv. 455, 467 (I989) (reviewing EISENBERG, supra note 72) ("the common law was the favorite target of the Realists"). This is true of some realists (like Felix Cohen), but for realists like Llewellyn (and even Jerome Frank) the common law, properly conceived, was an admirable institution. See Dan Priel, Legal Realisms (unpublished manuscript).
} 
That ideas, including political ideas, matter to understanding law is not a groundbreaking claim. Once again, in the context of particular legal rules, this idea is trivial. We fully expect, for example, a more conservative society to have more conservative laws. What I have attempted to show is that political ideas are relevant also for understanding the underlying philosophy of the common law, and that different political ideas will lead to different common law practice. Even at the more abstract level of the structure of legal institutions the claim, in some sense, is rather familiar. The dichotomy between "realism" and "formalism" has served to show how ideas influence central features of the practice. Unfortunately, this dichotomy is far too crude for providing an adequately nuanced account of the underlying ideologies of the common law. I have attempted to show that the four different ideal-types presented in this essay-reason, practice, custom, and will-as well as some potential combinations of them, provide a better way of understanding the familiar but littlediscussed divergences in what is still considered one of the unifying characteristics of the English-speaking world. 